\title{
Distribution of coccoliths in surface sediments across the Drake Passage and calcification of Emiliania huxleyi morphotypes
}

\author{
Nele Manon Vollmar ${ }^{1}$, Karl-Heinz Baumann ${ }^{1}$, Mariem Saavedra-Pellitero ${ }^{2}$, and \\ Iván Hernández-Almeida ${ }^{3}$ \\ ${ }^{1}$ University of Bremen, Department of Geosciences, P.O. Box 3304 40, 28334 Bremen, Germany \\ ${ }^{2}$ University of Birmingham, School of Geography, Earth and Environmental Sciences, Birmingham B15 2TT, UK \\ ${ }^{3}$ ETH Zürich, Geological Institute, Department of Earth Science, Sonneggstrasse 5, 8092, Zürich, Switzerland
}

Correspondence: Nele Manon Vollmar (nvollmar@uni-bremen.de)

\begin{abstract}
.
The Southern Ocean is experiencing rapid and profound changes in its physical and biogeochemical properties that may influence the distribution and composition of pelagic plankton communities. Coccolithophores are the most prolific carbonateproducing phytoplankton group playing an important role in Southern Ocean biogeochemical cycles. However, knowledge is scarce about the record of (sub-)fossil coccolith assemblages in the Southern Ocean, which are constituting invaluable indicators for paleoenvironmental reconstructions. This study investigates coccolith assemblages preserved in surface sediments of southernmost Chile and across the Drake Passage that were retrieved during R/V Polarstern Expedition PS97. We focused on the coccolith response to steep environmental gradients across the frontal system of the Antarctic Circumpolar Current and to hydrodynamic and post-depositional processes occurring in this region. We used statistical analyses to explore which environmental parameters influenced the coccolith assemblages by means of Cluster and Redundancy Analyses. We specifically assessed the morphological diversity of the dominant taxa, i.e. Emiliania huxleyi, emphasizing biogeographical variability of morphotypes, coccolith sizes and calcite carbonate mass estimations.

High coccolith abundances and species diversity compared to studies in the same area and in other sectors of the Southern Ocean occur, with a high species richness especially south of the Polar Front. While the surface sediments offshore Chile and north of the Polar Front provide suitable material to reconstruct overlying surface ocean conditions, further factors such as temporary thriving coccolithophore communities in the surface waters or transport of settling coccoliths via surface and bottom currents and eddies are influencing the (sub-)fossil coccolith assemblages south of the Polar Front. Additionally, deeper samples in the southern part of the study area are particularly affected by selective carbonate dissolution.

We identified five E. huxleyi morphotypes (A, A overcalcified, R, B/C and O), and estimated coccolith carbonate masses on the basis of scanning electron microscope images. E. huxleyi morphologies reflect diverging biogeographical distributions, trending towards smaller and lighter coccoliths to the south and emphasizing the importance of documenting those morphologies in relation to changing environmental conditions to assess their response to projected environmental change in the SO.
\end{abstract}


https://doi.org/10.5194/bg-2021-105

Preprint. Discussion started: 23 April 2021

(c) Author(s) 2021. CC BY 4.0 License.

(c) (i)

\section{Introduction}

The Southern Ocean (SO) surrounds Antarctica and connects the Atlantic, Indian and Pacific Oceans via the eastward flowing Antarctic Circumpolar Current (ACC), but it also connects low tropical latitudes with high polar latitudes. It is thus a critical component of the global ocean circulation and the climate system as well as an important ecozone hosting a broad range of interdependent flora and fauna (Chapman et al., 2020). Furthermore, it is a major upwelling region in which, because of iron and light limitations, primary production stays comparatively low, resulting in an effective return of nutrients to the surface waters (Morrison et al., 2014; Talley et al., 2011; Rintoul, 2018; Malone, 2016; Frölicher et al., 2014).

The SO surface oceanography is characterized by frontal regimes resulting from the existence of different water masses (Orsi et al., 1995; Chapman et al., 2020). These ACC fronts often correspond to jets and divide the SO water masses into zones of similar properties (Talley et al., 2011; Palter et al., 2013; Raymond, 2014; Chapman et al., 2020). The Subtropical Front (STF, Hofmann, 1985) marks the the northernmost extent of subantarctic waters and corresponds to the $7{ }^{\circ} \mathrm{C}$ isotherm (Park et al., 2019; Sokolov and Rintoul, 2009; Barré et al., 2011). The STF acts as a boundary to the subtropical, relative warm and salty water. South of the STF, the Subantarctic Front (SAF) marks the southernmost extent of relatively warm subantarctic surface water, and the Polar Front (PF) constitutes the boundary between the relatively warmer subantarctic and the cold Antarctic waters, defined as the northernmost extent of the $2{ }^{\circ} \mathrm{C}$ at $200 \mathrm{~m}$ depth, which often coincides with the seasonal maximum of sea-ice extent (e.g., Orsi et al., 1995; Kim and Orsi, 2014; Giglio and Johnson, 2016; Nghiem et al., 2016). South to the PF, the Antarctic Zone (AZ) is characterized by a thin surface layer of cold and fresh Antarctic Surface Water (ASW) from the Antarctic shelf zone. The AZ is bounded to the south by the southern ACC Front (sACCF) which approximately equals the maximum sea-ice extent in the cold season. Closer to Antarctica and seasonally covered by sea-ice, the Southern Zone (SZ) lies between the sACCF and the southern boundary (SB) of the ACC, where low oxygen Upper Circumpolar Deep Water (UCDW) upwells and becomes very cold and fresh ASW. The SB is the northern boundary of the very cold and nearly isothermal waters offshore Antarctica (continental zone, CZ).

It is known that phytoplankton, including coccolithophores as the modern ocean's dominant calcifying phytoplankton, play a fundamental role in the SO food web, in which carbon is consumed, respired, remineralized and sequestrated. Satellite remote sensing detected the existence of a region of elevated reflectance and particulate inorganic carbon between the STF and the PF, corresponding to high coccolithophore abundances. This so-called "Great Calcite Belt" usually occurs during austral summer (Balch et al., 2011, 2016). Phytoplankton production in this area also controls global primary production via the lateral export of nutrients to lower latitudes (e.g., Sarmiento et al., 2004; Palter et al., 2010). Because of their two-fold carbon utilization, via photosynthesis (drawing down $\mathrm{CO}_{2}$ from the atmosphere into the ocean, Deppeler and Davidson, 2017) and calcification (releasing $\mathrm{CO}_{2}$ into the surface water and atmosphere, Volk and Hoffert, 1985; Rost and Riebesell, 2004; Kohfeld and Ridgwell, 2009), the contribution of coccolithophores to the carbon cycle is particularly complex. Additionally, the ratio between production of particulate organic carbon and particulate incorganic carbon (essentially calcium carbonate) is dependent on the species, morphotype and the given biogeochemical conditions (Blanco-Ameijeiras et al., 2016; Findlay et al., 2011). The competitive interaction between coccolithophores and diatoms is also of particular relevance in the SO, with 
https://doi.org/10.5194/bg-2021-105

Preprint. Discussion started: 23 April 2021

(c) Author(s) 2021. CC BY 4.0 License.

(c) (i)

the former being prevalent north of the PF, while the second dominating in regions south of it (e.g., Saavedra-Pellitero and Baumann, 2015; Balch et al., 2016; Malinverno et al., 2016; Cárdenas et al., 2019). Models have shown that coccolithophores contribute $16.5 \%$ to the total annual net primary production south of $30^{\circ} \mathrm{S}$, which is $5 \%$ of the global annual net primary production (e.g., Nissen et al., 2018). The model simulation by Nissen et al. (2018) fits well with field observations made in the plankton during the last years, which have shown that the majority of the species, but also the number of individuals, decrease at the PF and southwards (e.g., Mohan et al., 2008; Patil et al., 2013; Saavedra-Pellitero et al., 2014, 2019; Charalampopoulou et al., 2016; Malinverno et al., 2015, 2016).

One common observation is the general dominance of Emiliania huxleyi in extant coccolithophore assemblages with a southward displacement of morphotype A by the more weakly calcified morphotypes of morphogroup B (Cubillos et al., 2007; Boeckel et al., 2006; Mohan et al., 2008; Charalampopoulou, 2011; Patil et al., 2013, 2014; Saavedra-Pellitero et al., 2014, 2019). In fact, specimens of E. huxleyi with variable degree of calcification within the same morphotype have been previously observed in the South Pacific, offshore Chile and in the Patagonian fjords, being especially evident in morphotypes A and R (e.g., Beaufort et al., 2008, 2011; Rigual Hernández et al., 2018; von Dassow et al., 2018; Saavedra-Pellitero et al., 2019; DíazRosas et al., 2021). The southernmost extent of coccolithophores in SO plankton with monospecific occurrence of E. huxleyi is approximately located at the sACCF, although often its abundance is already very low south of the PF (Malinverno et al., 2015; Saavedra-Pellitero et al., 2019). However, more southwards shifts in the occurrence or abundance of coccolithophores and assemblage composition have already been observed and modelled in recent years (e.g., Winter et al., 2014; Krumhardt et al., 2019). Repeated sampling in the Australian sector of the SO over the past four decades has shown a dramatic range expansion of coccolithophores south of $60^{\circ} \mathrm{S}$, dominated by the globally ubiquitous species E. huxleyi (Cubillos et al., 2007). Here, any ocean acidification effect appears outweighed by surface-ocean warming. The influence of carbonate chemistry in the calcite production of coccoliths has also been noted in culture experiments, it however showed conflicting results in the literature. While in several experiments increased $p \mathrm{CO}_{2}$ concentrations led to reduced calcification rates, other experiments showed no response or even increased calcification rates (Meyer and Riebesell, 2015 and references therein).

Considering that the SO biological calcification is known to exert a powerful control on the global distribution of alkalinity (Krumhardt et al., 2020), the extent to which those southward shifts are exclusively of recent origin could possibly be reconstructed on the basis of the occurrences of coccoliths in surface sediments. However, the number of coccolithophore studies in surface sediment in this area is very limited, and they mostly focus on assemblages. Understanding and predicting the impact of the already ongoing SO acidification and warming on the calcifying plankton is nowadays a key research challenge. While the relationship between environmental parameters and the community composition, biogeography and calcification mode of $E$. huxleyi in extant coccolithophore communities across the Drake Passage (DP) was already assessed by Saavedra-Pellitero et al. (2019), this work focuses on the transformation and record of living polar coccolithophores into fossil coccolith assemblages preserved in underlying recent sediments. The aims of the present study are to investigate if the biogeographical distribution of the coccolith assemblages in surface sediments across the DP reflect the steep environmental gradients marked by the frontal systems and to assess if (and how) they are affected by the hydrodynamic and post-depositional processes in this region. Additionally, we evaluated the coccolith mass variations in the dominant taxa E. huxleyi within each different morphotype. The 
https://doi.org/10.5194/bg-2021-105

Preprint. Discussion started: 23 April 2021

(c) Author(s) 2021. CC BY 4.0 License.

(c) (i)

analysis of pre-industrial assemblages by using a suite of well-preserved surface sediment allowed us to compare to the available plankton data (Saavedra-Pellitero et al., 2019) and will constitute an invaluable dataset for future potential palaeoproxy calibrations and climate models, covering an existing gap in the literature of the SO.

\section{Study Area}

The study area covers the Chilean margin south of $52^{\circ} \mathrm{S}$ together with the western part of the Drake Passage (DP, see Figure 1). Off the Chilean margin, the relatively narrow but strong Cape Horn Current (CHC) transports low salinity and modified ACC waters into the Atlantic through the northern DP (Chaigneau, 2005; Strub et al., 1998). Two further poleward flowing currents, the surface Peru-Chile Countercurrent transporting equatorial waters, and the subsurface Peru-Chile Undercurrent transporting warm and high-nutrient waters (Karstensen and Ulloa, 2009; Strub et al., 1998), reach approximately the area where the $\mathrm{CHC}$ diverges from the ACC at around $40^{\circ} \mathrm{S}$ (not shown in the map). The DP represents the narrowest strait through which the ACC flows, resulting in a strong concentration of the oceanic fronts (Park et al., 2019; Barré et al., 2011), and hence large environmental changes across a relatively small space. In general, sea surface temperature decreases southwards while nutrients (e.g., nitrate, phosphate, silicate) increase polewards across the DP. While fronts amplify vertical mixing, their associated strong jets diminish horizontal mixing (Chapman et al., 2020) and as such, they can act as biological barriers for nonmotile plankton (such as coccolithophores). However, fronts are very dynamic in the DP, as they meander, merge, and split over short timescales (i.e., weeks, see Barré et al., 2011 for a detailed analysis of the DP), enhancing water exchange. The latter is also supported by emerging eddies along the fronts, which are capable of transporting water masses across fronts. Especially the Polar Front Zone (PFZ), between the SAF and PF, and the AZ, south of the PF, are both characterized by anticyclonic and cyclonic eddies (Barré et al., 2011; Talley et al., 2011) which influence the surface water temperatures and nutrient contents in the DP depending on the season. While anticyclonic eddies normally upwell deep, cold and nutrient-rich waters and enhance primary production in austral winter and spring, this mechanism seems to reverse in austral autumn and summer (Dawson et al., 2018).

The DP is furthermore known for strong bottom currents, so winnowing and trapping of sediment are common in this area (Lamy, 2016; Wu et al., 2019). Modern bottom flow speed in proximity to the frontal jets lies between 10 to $25 \mathrm{~cm} / \mathrm{s}$ (Renault et al., 2011; Donohue et al., 2016) and was estimated to be between $12 \mathrm{~cm} / \mathrm{s}$ and $22 \mathrm{~cm} / \mathrm{s}$ at the modern SAF location in the Holocene (Toyos et al., 2020). Despite these strong bottom currents, the surface sediments in the DP show a clear trend between the composition of surface sediments and ocean productivity, terrigenous input, intensity of ocean currents, and ice proximity (Wu et al., 2019; Cárdenas et al., 2019).

A general N-S transition from carbonate-rich to opal-rich sediment is observed within the DP surface sediments (Cárdenas et al., 2019). Relatively high carbonate contents of $>45$ weight $\%$ in the SAZ along the Chilean and Argentinian margins decrease in the subantarctic waters of the AZ south of the PF and become extremely low (mean 2.4 weight \%) in the surface sediments of the SZ and CZ south of the sACCF (Raymond, 2014; Cárdenas et al., 2019; Wu et al., 2019). Diatom concentrations at and south of the PF are generally one order of magnitude higher than north of it. Diatom distribution clearly reflects the N-S environmental gradients of sea surface temperature and sea ice extent, and the assemblage distribution characterize the 
https://doi.org/10.5194/bg-2021-105

Preprint. Discussion started: 23 April 2021

(c) Author(s) 2021. CC BY 4.0 License.

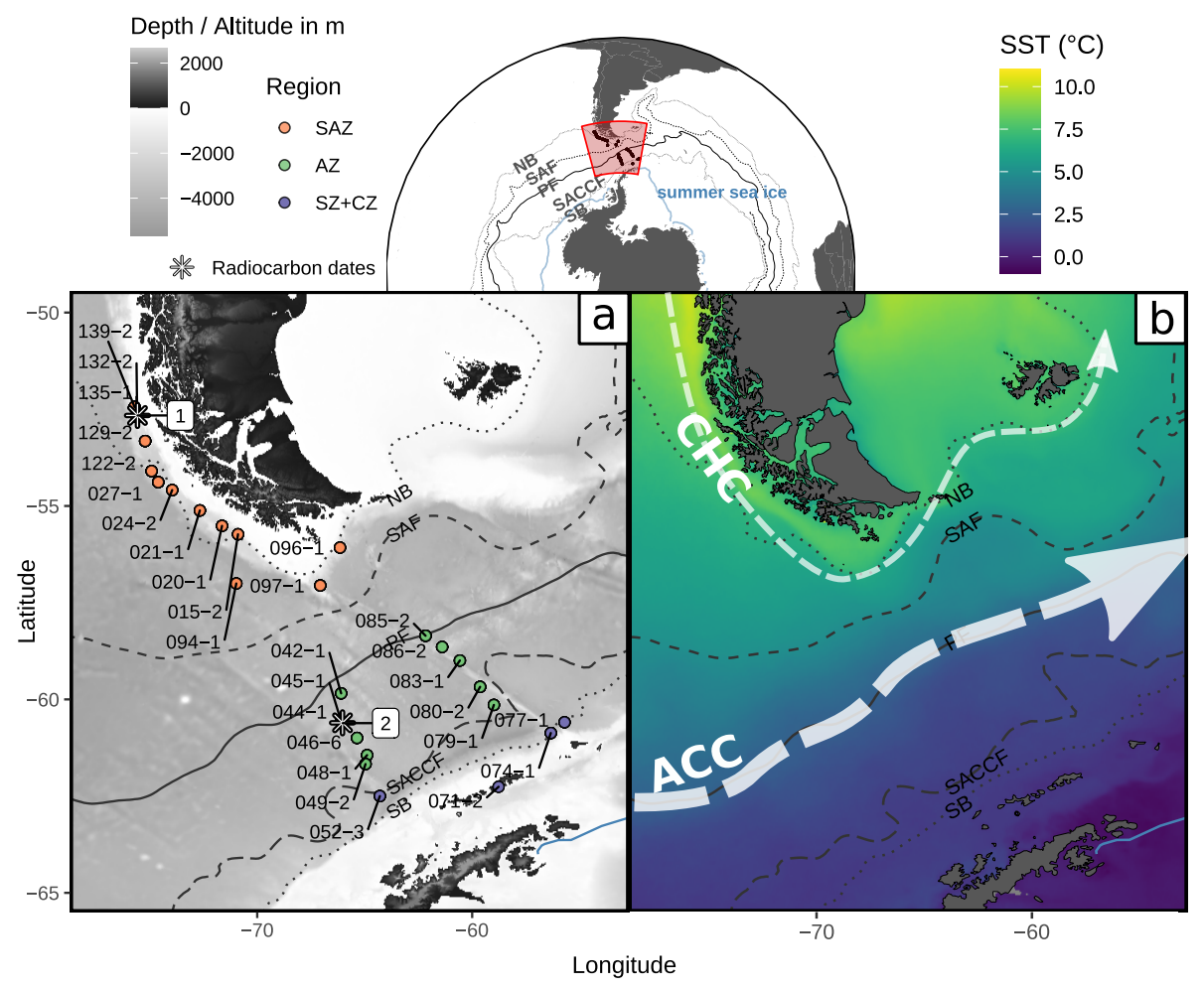

Figure 1. Study area in the Drake Passage, Southern Ocean, showing (a) locations of the studied surface sediment samples from expedition PS97 (Lamy, 2016) and radiocarbon dates (1 from Caniupán et al. (2011b) and 2 from Vorrath et al. (2019)) and (b) sea surface temperature composite (MODIS-Aqua 2002-2020 cumulative L3m 4km product distributed by the Ocean Biology Distributed Active Archive Center as AQUA_MODIS.20020704_20200831.L3m.CU.SST.sst.4km.nc based on NASA/JPL (2020)) with main currents after Lamy et al. (2015); Kaiser et al. (2005): CHC (Cape Horn Current), ACC (Antarctic Circumpolar Current). Dotted and dahed lines depict the ACC fronts (from Park and Durand, 2019) from north to south: NB (Northern Boundary), SAF (Subantarctic Front, PF (Polar Front), sACCF (southern ACC Front), SB (Southern Boundary). Blue line depicts the approximate summer sea ice extent. Base map dataset from Natural Earth (naturalearthdata.com).

different frontal zones (Raymond, 2014; Cárdenas et al., 2019). Furthermore, terrigenous sediments in the DP region mainly originate from proximal terrestrial sources such as Patagonia and the Antarctic Peninsula, as shown by a comparable set of surface sediment samples (Wu et al., 2019). Estimated holocene sedimentation rates in the DP area are in the order of $3.5 \mathrm{~cm} / \mathrm{kyr}$ (Ho et al., 2012) or $3.79 \mathrm{~cm} / \mathrm{kyr}$ (Caniupán et al., 2011a).

\section{Material and Methods}

In total, 28 surface sediment samples from the southern Chilean and Argentinian margin and the DP were prepared and analysed for this coccolithophore study (Figure 1). All samples were retrieved with a multicorer sampling device from February to April 
https://doi.org/10.5194/bg-2021-105

Preprint. Discussion started: 23 April 2021

(C) Author(s) 2021. CC BY 4.0 License.

(c) (i)

2016 during expedition PS97 (Lamy, 2016). Datings of near-surface sediments at the southern Chilenean margin (Caniupán et al., 2011b) as well as south of the PF within the DP (Vorrath et al., 2019) give calibrated accelerator mass spectrometry (AMS) ${ }^{14} \mathrm{C}$ ages of $2.91-3.06 \mathrm{ka} \mathrm{BP}$ and $4.83 \mathrm{ka}$ BP respectively. We therefore assume that our studied surface sediments represent relatively modern conditions, with ages ranging most likely from mid to late Holocene.

The uppermost centimetre of the multicores were sampled and prepared with a combined dilution/filtering technique following Andruleit (1996). Between 66 and $153 \mathrm{mg}$ of dry bulk sediment per sample were suspended in demineralized water buffered with ammonia and ultrasonicated for up to $30 \mathrm{~s}$. The suspensions were split to one-hundredth with a rotary sample divider, filtered through polycarbonate membrane filters with a pore size of $0.45 \mu \mathrm{m}$, and dried in an oven at $40{ }^{\circ} \mathrm{C}$ for $24 \mathrm{~h}$. Out of the dried filters, a piece of approximately $1 \mathrm{~cm}^{2}$ was cut out, mounted on an aluminium scanning electron microscope (SEM) stub, fixed with carbon conductive tabs and sputter-coated with gold-palladium. The filters were analysed with a Zeiss DSM 940A SEM at a magnification of 3000x for coccolith species abundance counts, and of minimum 5000x for E. huxleyi morphotype identification and abundances. A minimum of 300 coccoliths per sample was counted in transects across the filter area, except for eight relatively coccolith-poor samples south of the PF and two in the SAZ in which at least 100 coccoliths were aimed to be counted. All the sampling points were considered when plotting the number of coccoliths per gram of sediment, except for three sample with extremely low counts that were excluded in the plots of relative abundances. The number of coccoliths per gram of sediment (Coc/g sed.) were calculated using the formula from Andruleit (1996):

Coc/g sed. $=\frac{F c \cdot C c \cdot S p}{A \cdot W}$

in which, $F c=$ effective filtration area $\left(\mathrm{mm}^{2}\right) ; C c=$ number of counted coccoliths; $S p=$ split factor; $A=$ investigated filter area, and $W=$ weight of bulk dry sediment.

Furthermore, a preservation index (Calcidiscus leptoporus - Emiliania huxleyi Dissolution Index, CEX) adopted from Dittert et al. (1999) was calculated in order to check whether the coccolith assemblages were influenced by carbonate dissolution. The CEX is based on the differential dissolution behaviour of the delicate E. huxleyi versus the more robust $C$. leptoporus and has proven to be comparable to dissolution indices based on foraminiferal tests.

The assemblage diversity was assessed using the Shannon Index:

Shannon diversity $=-\sum_{i=1}^{S} p_{i} \log _{2} p_{i}$

with $p_{i}=$ proportion of species $i$, and $S=$ number of species. 
https://doi.org/10.5194/bg-2021-105

Preprint. Discussion started: 23 April 2021

(C) Author(s) 2021. CC BY 4.0 License.
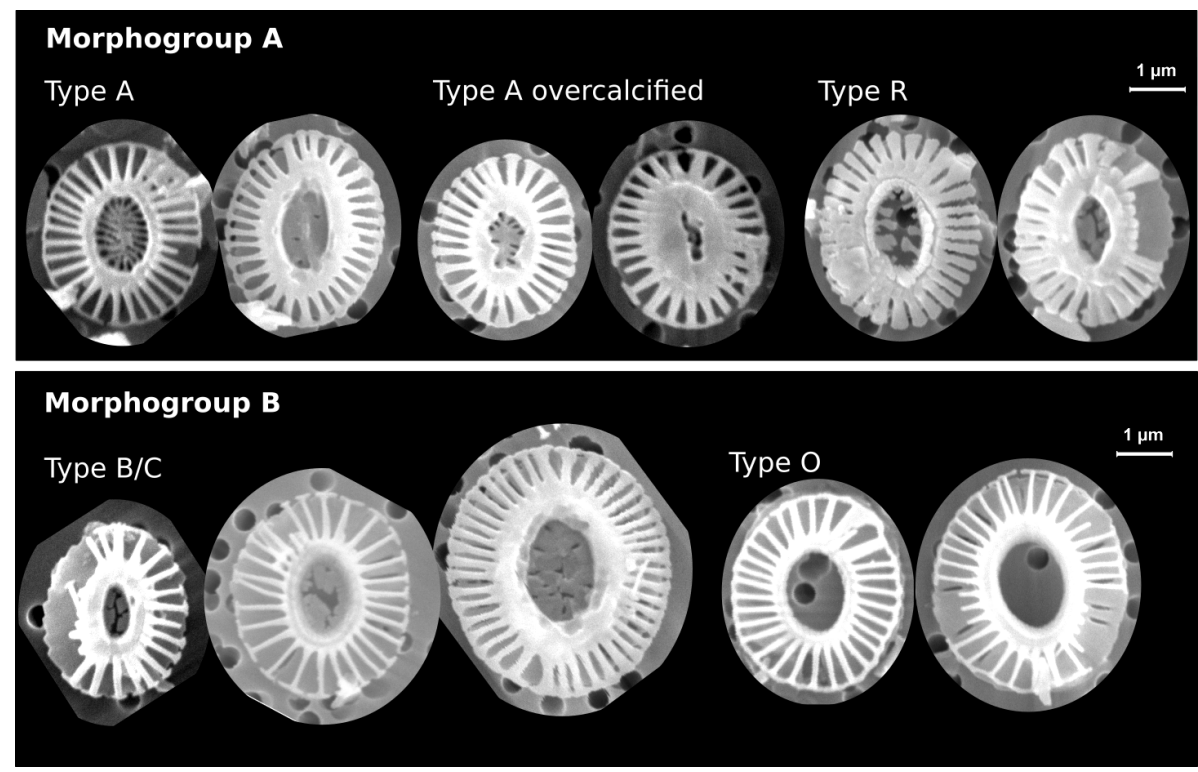

Figure 2. Examples of identified Emiliania huxleyi morphotypes in this study. The scale bar is $1 \mu \mathrm{m}$ and equal among all displayed coccoliths. In morphogroup A, we identified morphotypes A, A overcalcified and R; in morphogroup B we identified morphotypes B/C and O based on the central area feature. Note the large size variation within morphotype B/C. See Table 1 for a classification summary of the different morphotypes.

\subsection{Species and morphotype taxonomy}

Coccoliths were classified at species level following Young et al. (2003) and the electronic guide to the biodiversity and taxonomy of coccolithophores Nannotax 3 by (Young et al., 2020). Specific taxonomical considerations regarding E. huxleyi specimens were taken into account, and morphotypes were differentiated as far as it was possible on single coccoliths directly during the counts.

In an additional count, we differentiated between five E. huxleyi morphotypes within morphogroups A and B. These are: Type A, Type A overcalcified and Type $\mathrm{R}$ (comprised in morphogroup A) as well as Type B/C and Type $\mathrm{O}$ (within morphogroup B). Our approach thus slightly differs from the morphotype identification of Saavedra-Pellitero et al. (2019) within morphogroup B. Due to the fact that we could not always distinguish with certainty between Types B, B/C and C, we considered here Type $\mathrm{B} / \mathrm{C}$ as a mixed classification for coccoliths resembling characteristics of these 3 types, with a size ranging across the typical threshold at $3.5 \mu \mathrm{m}$ (Young et al., 2003; Cubillos et al., 2007). In our studied samples, size was the only coherent characteristic that differed between specimens within morphogroup B (excluding morphotype $\mathrm{O}$ ) with a normal distribution maximum between approximately 3 and $4 \mu \mathrm{m}$ and showing no indication for distinct morphotype distributions (See Table 1 and Figure 2). Hence, we classified all E. huxleyi coccoliths from morphogroup B into either Type B/C or Type O, depending on the central area (Hagino et al., 2011). 
https://doi.org/10.5194/bg-2021-105

Preprint. Discussion started: 23 April 2021

(c) Author(s) 2021. CC BY 4.0 License.

(c) (i)

Table 1. Identified Emiliania huxleyi morphotypes and classification summary based on Young et al. (2020); Hagino et al. (2011); SaavedraPellitero et al. (2019). See Figure 2 for example images for the respective morphotypes.

\begin{tabular}{llll}
\hline Morphogroup & Morphotype & Morphology of distal shield & Morphology of central area \\
\hline A & $\begin{array}{l}\text { Type A } \\
\text { Type A overcalcified }\end{array}$ & $\begin{array}{l}\text { Moderately to heavily calcified elements } \\
\text { Moderately to heavily calcified elements, } \\
\text { broad inner tube } \\
\text { Reticulofenestra-like, } \\
\text { heavily calcified distal shield }\end{array}$ & $\begin{array}{l}\text { Grill } \\
\text { Closed or nearly closed }\end{array}$ \\
& Type R & Grill \\
\hline B & $\begin{array}{l}\text { Tightly calcified and well separated elements } \\
\text { Lyphtly calcified elements, elevated }\end{array}$ & $\begin{array}{l}\text { Solid, plated, laths with irregular outline } \\
\text { Open }\end{array}$ \\
\hline
\end{tabular}

\subsection{Emiliania huxleyi morphometry and mass estimation}

For a subset of 22 samples, the morphometry of E. huxleyi coccoliths was performed and analysed on 613 SEM micrographs of single flat-lying E. huxleyi coccoliths at a magnification of 10000x. Images of E. huxleyi coccoliths were measured with the Coccobiom 2 macro (Young, 2015) in Fiji software (Schindelin et al., 2012). Measurements were done in $\mu \mathrm{m}$ based on the scalebar of the SEM images. They were scaled to $100 \%$ with a Coccobiom2 SEM calibration of 1.09 and the chosen magnification.

From the morphometrical measurements on E. huxleyi the coccolith masses were estimated based on two different formulas, that of Beuvier et al. (2019) and that of Young and Ziveri (2000). Beuvier et al. (2019) studied coccospheres and coccoliths of 7 different Noëlaerhabdaceae species including three strains of E. huxleyi by means of X-ray nanotomography. They found that coccolith mass correlates with grid perimeter and with crystal number. They developed the following empirical formula (Equation 4) to calculate the coccolith mass $m$ in pg from the number of segments $n$ (with two constants $k_{n}=4.73 * 10^{-5}$ ( \pm $0.28 * 10^{-5}$ ) and $\beta=3.175 \pm 0.251$ ). This is based on a calcite density of $2.71 \mathrm{pg} \mu \mathrm{m}^{3}$. However, this formula does not account for calcification of the central area itself, as found in the E. huxleyi morphotype A overcalcified observed in this study.

$m=k_{n} \cdot n^{\beta}$

We additionally used the well established approach to estimate coccolith masses by Young and Ziveri (2000). Their approach (Equation 5) is based on the length $l$ of a coccolith together with a species-specific and morphotype-specific shape factor $k_{s}$,

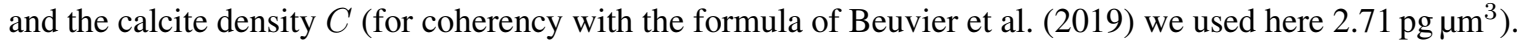

$m=C \cdot k_{s} \cdot l^{3}$ 
https://doi.org/10.5194/bg-2021-105

Preprint. Discussion started: 23 April 2021

(c) Author(s) 2021. CC BY 4.0 License.

\section{(c) (i)}

The different shape factors used were based on the identified morphotype following Young and Ziveri (2000): $k_{s}=0.02$ for morphotypes $\mathrm{A}$ and $\mathrm{B} / \mathrm{C}$ and $k_{s}=0.04$ for morphotype $\mathrm{A}$ overcalcified. The shape factor for morphotype $\mathrm{O}\left(k_{s}=0.15\right)$ was introduced by Poulton et al. (2011) in a plankton study along the Patagonian shelf for a morphotype with a central area described as "open or thin plate" which the authors called Type B/C but that we identified as morphotype O (see Hagino et al., 2011). The approach of performing morphometric measurements on the coccoliths followed by the estimation of their coccolith mass assuming a systematic relation between length and thickness was chosen because all data were determined on the same material using SEM. Rigual Hernández et al. (2020) compared coccolith carbonate estimates from a birefringencebased approach with the morphometrics-based approache from Young and Ziveri (2000), and showed, on average, slightly higher but largely comparable carbonate contents for E. huxleyi coccoliths using the latter approach.

\subsection{Environmental parameters}

We used biogeochemical parameters to test how much of the species assemblage composition could be explained by environmental factors (see also subsection 3.4). Those are annual salinity, temperature and phosphate at $10 \mathrm{~m}$ water depth which we extracted from the $1^{\circ}$ GLODAPv2 mapped climatology (Lauvset et al., 2016; Key et al., 2015) to stay consistent with the calculated carbon system parameters based on the same data product. Carbon system parameters for the location of each sample at its respective water depth were calculated using $\mathrm{CO}_{2} \mathrm{SYS}$ macro for PC (Pierrot et al., 2012) based on salinity, temperature, silicate, phosphate, alkalinity and total $\mathrm{CO}_{2}$. The data from GLODAPv2 and the derived carbonate system data have a seasonal bias towards southern hemisphere winter (December to March) because samples in this database were mostly taken during the austral summer (Lauvset et al., 2016). Coccolithophores in the southeast Pacific sector of the SO bloom mostly during austral spring and summer months (Balch et al., 2016; Nissen et al., 2018), and thus the coccolithophore assemblages in surface sediments are biased towards the same season as the environmental dataset.

Austral winter Photosynthetic Available Radiation (PAR) at $10 \mathrm{~m}$ water depth was estimated using a model of light penetration (Buiteveld, 1995; Murtugudde et al., 2002), the diffuse atternuation coefficient for downwelling irradiance at $490 \mathrm{~nm}$ and Equation 1 in Lin et al. (2016). Mixed layer depth (MLD) was extracted from monthly $1^{\circ}$ ARGO MLD climatology (Holte et al. (2017), based on a density algorithm). Data from austral spring and summer months (September to March) were averaged, and extracted from the respective sample positions.

\subsection{Statistical analyses}

Prior to any statistical analysis, we excluded three samples (PS97/077-1, PS97/079-1 and PS97/071-2) because of the very low number of coccoliths counted ( $<40$ per sample). A detrended correspondence analysis (DCA) was applied on the species relative abundance dataset resulting in a first axis length of $1 \mathrm{SD}$ suggesting a short gradient for which linear ordination methods are suitable. The relative abundance data was standardized using Hellinger transformation (giving low weights to rare species, Legendre and Gallagher, 2001), using R package adespatial 0.3-8 (Dray et al., 2020).

Average-linkage (UPGMA) hierarchical clustering was performed on the assemblage data with R function hclust (R Core Team, 2020). The best number of clusters was suggested by the majority of 30 indices calculated with $\mathrm{R}$ package NbClust 
https://doi.org/10.5194/bg-2021-105

Preprint. Discussion started: 23 April 2021

(C) Author(s) 2021. CC BY 4.0 License.

\section{(c) (i)}

version 3.0 (Charrad et al., 2014). The significance of each cluster was assessed by multiscale bootstrap resampling with 10000 replications using $\mathrm{R}$ package pvclust version 2.2-0 (Suzuki et al., 2019).

To perform transformation-based RDA (tb-RDA), we constrained our assemblage data (response, 16 species at 25 sites) to seven standardized environmental variables (explanatory): salinity, temperature, phosphate and PAR at $10 \mathrm{~m}$ water depth; $\mathrm{CO}_{3}$ as representative variable for the carbonate system at surface sediment sample depth; the MLD and the respective surface sediment sample depth itself. The adjusted $\mathrm{R}^{2}$ was calculated and the significance of the tb-RDA was tested at 9999 permutations. Analysis was performed using R package vegan version 2.5-6 (decostand, rda, RsquareAdj, anova.cca, Oksanen et al., 2019). We also calculated the analogue distance of a subset of the sediment surface samples to the nearest plankton samples (Saavedra-Pellitero et al., 2019) using R package ggpalaeo version 0.0.0.9005 (Telford, 2019), see Figure A3. All figures were made with R package ggplot2 version 3.3.2 (Wickham, 2016) and Inkscape version 1.0.2 .

\section{Results}

Coccoliths were found in all the oceanographic zones bounded by the fronts, with generally high absolute numbers in the $\mathrm{SAZ}$ and comparatively low numbers in the $\mathrm{AZ}$ and $\mathrm{SZ}+\mathrm{CZ}$. The abundance ranges from $9 * 10^{6} \mathrm{Coc} / \mathrm{g}$ sed. in the SZ+CZ (at PS97/077-1) to $4159 * 10^{6} \mathrm{Coc} / \mathrm{g}$ sed. in the SAZ (at PS97/020-1). We unexpectedly found a quite diverse coccolith assemblage with a total of 23 identified species, ranging from 6 to 15 different taxa per station.

Highest numbers of coccoliths were recorded in the deepest samples studied along the Chilean margin (1.8 to $2.5 \mathrm{~km}$ water depth) with $2669 * 10^{6}$ to $4159 * 10^{6} \mathrm{Coc} / \mathrm{g}$ sed. belonging to different taxa, ranging from 7 to 14 different species depending on the station (Figure 3). The shallower surface sediment samples analysed in this study, located in the northernmost area offshore Chile ( 0.5 to $1.3 \mathrm{~km}$ water depth) bore 10 to 15 different species but contained relatively low coccolith numbers of ca. 591 to $1023 * 10^{6} \mathrm{Coc} / \mathrm{g}$ sed. The samples along the Argentinian margin, in an open ocean setting (from 1.6 to $4 \mathrm{~km}$ water depth), yielded only 199 to $472 * 10^{6} \mathrm{Coc} / \mathrm{g}$ sed. belonging to 6 to 10 different species. The samples south of the PF, located in the AZ, were retrieved from water depths of at least $1.2 \mathrm{~km}$ but mostly of 3 to $4 \mathrm{~km}$. We found similar numbers of coccolith species than at lower latitudes (from 6 to 13 taxa), but the coccolith contents considerably decreased $\left(22 * 10^{6}\right.$ to $645 * 10^{6} \mathrm{Coc} / \mathrm{g}$ sed.), especially in the deeper samples, below $3.1 \mathrm{~km}$. Even some of the southernmost samples in the SZ+CZ along the Antarctic margin (PS97/074-1 and PS97/052-3) yielded a content of 57 and $141 * 10^{6}$ Coc/g sed. from 12 and 9 species, respectively. Lowest total coccolith abundances were found in two samples in the SZ+CZ (PS97/071-2, PS97/077-1) and AZ (PS97/079-1) with 9 to $22 * 10^{6} \mathrm{Coc} / \mathrm{g}$ sed. Because of the low total coccolith counts $<40$ in these three samples, we did not consider them for further analyses (see Table 2).

\subsection{Species composition and distribution}

All surface sediment coccolith assemblages in the study area consist of E. huxleyi, Gephyrocapsa muellerae and Calcidiscus leptoporus (intermediate morphotype; hereafter only referred to as C. leptoporus according to Baumann et al., 2016) and in all, except in one sample, we identified Gephyrocapsa ericsonii as a main contributor. Those species make up on average 
https://doi.org/10.5194/bg-2021-105

Preprint. Discussion started: 23 April 2021

(c) Author(s) 2021. CC BY 4.0 License.

Table 2. Sample main metadata (Lamy, 2016), frontal zone, total counted coccoliths, coccolith abundance and species richness. The lowermost three samples yielded very low total coccolith counts and were excluded from statistical analyses.

\begin{tabular}{|c|c|c|c|c|c|c|c|}
\hline Station & Latitude in ${ }^{\circ} \mathrm{S}$ & Longitude in ${ }^{\circ} \mathrm{W}$ & frontal zone & water depth in $\mathrm{m}$ & total counted & abundance $* 10^{6}$ & species richness \\
\hline $139-2$ & 52.44 & 75.71 & SAZ & 639 & 406 & 596.48 & 14 \\
\hline $132-2$ & 52.62 & 75.59 & SAZ & 843 & 330 & 591.42 & 10 \\
\hline $135-1$ & 52.70 & 75.59 & SAZ & 1094 & 365 & 807.99 & 15 \\
\hline $129-2$ & 53.32 & 75.21 & SAZ & 1879 & 370 & 2669.92 & 12 \\
\hline $122-2$ & 54.10 & 74.91 & $\mathrm{SAZ}$ & 2560 & 314 & 3305.55 & 11 \\
\hline $027-1$ & 54.38 & 74.61 & SAZ & 2349 & 340 & 3089.65 & 14 \\
\hline $024-2$ & 54.59 & 73.95 & SAZ & 1273 & 308 & 1023.91 & 9 \\
\hline $021-1$ & 55.12 & 72.67 & SAZ & 1840 & 316 & 3078.35 & 9 \\
\hline $020-1$ & 55.51 & 71.64 & $\mathrm{SAZ}$ & 2104 & 325 & 4159.29 & 10 \\
\hline $015-2$ & 55.73 & 70.89 & SAZ & 1878 & 317 & 2897.79 & 7 \\
\hline 096-1 & 56.08 & 66.15 & SAZ & 1621 & 212 & 199.29 & 8 \\
\hline 094-1 & 57 & 70.97 & SAZ & 3993 & 103 & 239.12 & 6 \\
\hline $097-1$ & 57.05 & 67.07 & SAZ & 2319 & 319 & 472.89 & 10 \\
\hline $085-2$ & 58.35 & 62.17 & $\mathrm{AZ}$ & 3091 & 330 & 569.10 & 13 \\
\hline $086-2$ & 58.64 & 61.40 & $\mathrm{AZ}$ & 2969 & 327 & 628.13 & 9 \\
\hline 083-1 & 58.99 & 60.57 & $\mathrm{AZ}$ & 3756 & 101 & 29.69 & 7 \\
\hline $080-2$ & 59.67 & 59.63 & $\mathrm{AZ}$ & 3113 & 182 & 202.18 & 10 \\
\hline $042-1$ & 59.84 & 66.10 & $\mathrm{AZ}$ & 4172 & 105 & 156.02 & 9 \\
\hline $045-1$ & 60.57 & 66.09 & $\mathrm{AZ}$ & 2292 & 313 & 645.80 & 7 \\
\hline 044-1 & 60.61 & 66.02 & $\mathrm{AZ}$ & 1203 & 121 & 226.96 & 6 \\
\hline 074-1 & 60.87 & 56.34 & $\mathrm{SZ}+\mathrm{CZ}$ & 1831 & 111 & 57.37 & 12 \\
\hline $046-6$ & 61 & 65.36 & $\mathrm{AZ}$ & 2803 & 309 & 218.59 & 13 \\
\hline $048-1$ & 61.44 & 64.89 & $\mathrm{AZ}$ & 3455 & 103 & 86.11 & 7 \\
\hline $049-2$ & 61.67 & 64.96 & $\mathrm{AZ}$ & 3752 & 101 & 39.23 & 10 \\
\hline $052-3$ & 62.50 & 64.29 & $\mathrm{SZ}+\mathrm{CZ}$ & 2890 & 178 & 141.01 & 9 \\
\hline 079-1 & 60.14 & 58.99 & $\mathrm{AZ}$ & 3539 & 34 & 22.13 & 7 \\
\hline $077-1$ & 60.59 & 55.70 & $\mathrm{SZ}+\mathrm{CZ}$ & 3586 & 10 & 8.96 & 5 \\
\hline $071-2$ & 62.26 & 58.77 & $\mathrm{SZ}+\mathrm{CZ}$ & 441 & 6 & 15.91 & 3 \\
\hline
\end{tabular}

$94 \%$ of the coccolith assemblages in the SAZ, $93 \%$ in the AZ and $87 \%$ in the SZ+CZ. Additionally, C. leptoporus small, Florisphaera profunda, Gephyrocapsa oceanica, Helicosphaera carteri and Syracosphaera spp. are present in low relative numbers in several of the DP and the Chilean margin studied stations (see Figure 4). 
https://doi.org/10.5194/bg-2021-105

Preprint. Discussion started: 23 April 2021

(C) Author(s) 2021. CC BY 4.0 License.

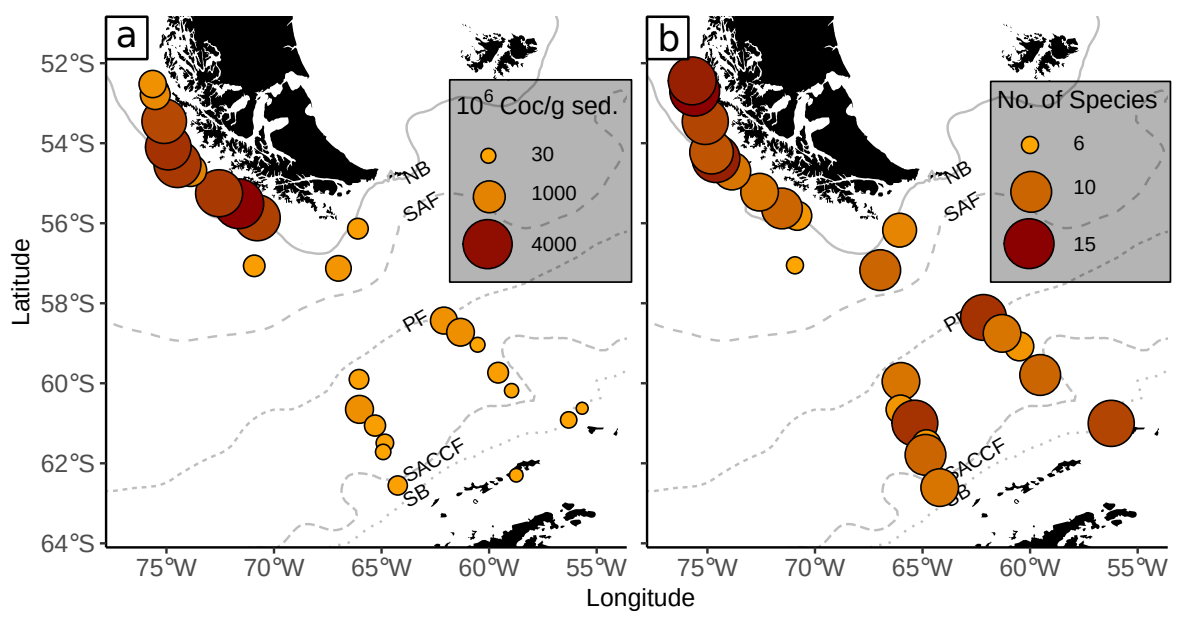

Figure 3. (a) Total numbers of coccolith as well as (b) numbers of coccolith species in the studied surface sediments of the DP. Data from stations PS97/071-2, 077-1 and 079-1 are only shown in (a). ACC Fronts from north to south: NB (Northern Boundary), SAF (Subantarctic Front), PF (Polar Front), sACCF (southern ACC Front), SB (Southern Boundary).

The majority of the surface sediment assemblages are dominated by $E$. huxleyi coccoliths with average abundances of $72 \%$ in the SAZ, $60 \%$ in the AZ and $37 \%$ in the SZ+CZ. Emiliania huxleyi gets replaced by gephyrocapsids (G. muellerae and G. ericsonii) and C. leptoporus at the deeper stations (i.e. below $3.1 \mathrm{~km}$ ), from the SAZ (gephyrocapsids: $30 \%$, C. leptoporus: $40 \%$ ) and AZ (gephyrocapsids: $36 \%$, C. leptoporus: 19\%) to the SZ+CZ (gephyrocapsids: $47 \%$, C. leptoporus: $6 \%$ ). Gephyrocapsa muellerae and G. ericsonii are found in all stations, while G. oceanica is not observed in some samples from the SAZ along the Chilean margin and is completely absent in the open ocean SAZ. Following those gephyrocapsids, the next most abundant coccoliths are belonging to the family Calcidicaceae (mainly C. leptoporus), which makes up $13 \%$ in average of the coccolith assemblage. Calcidiscus leptoporus is found in every sample, while C. leptoporus small is missing in some samples from the SAZ along the Chilean margin and in one sample from the SZ+CZ (Figure 4). Calcidiscus quadriperforatus is exclusively present in samples along the Chilenean margin. Noteworthy minor species include F. profunda, H. carteri and Syracosphaera spp. with average relative abundances of maximum $2 \%$ and with occurrences in all frontal zones (Figure 4). Other species scattered across all biogeographic zones are Reticulofenestra sessilis, Umbellosphaera spp. Coccolithus braarudii, Algirosphaera robusta, and other unidentified taxa. Rare species include Syracosphaera pulchra, Umbilicosphaera foliosa, Umbilicosphaera sibogae, Calciosolenia brasiliensis, Coccolithus pelagicus, Oolithotus fragilis, Umbellosphaera hulburtiana, Coronosphaera mediterranea, Pontosphaera spp. and further reworked specimens scattered across the DP in 3 Stations (Figure A1). See the supplementary material for further details. 
https://doi.org/10.5194/bg-2021-105

Preprint. Discussion started: 23 April 2021

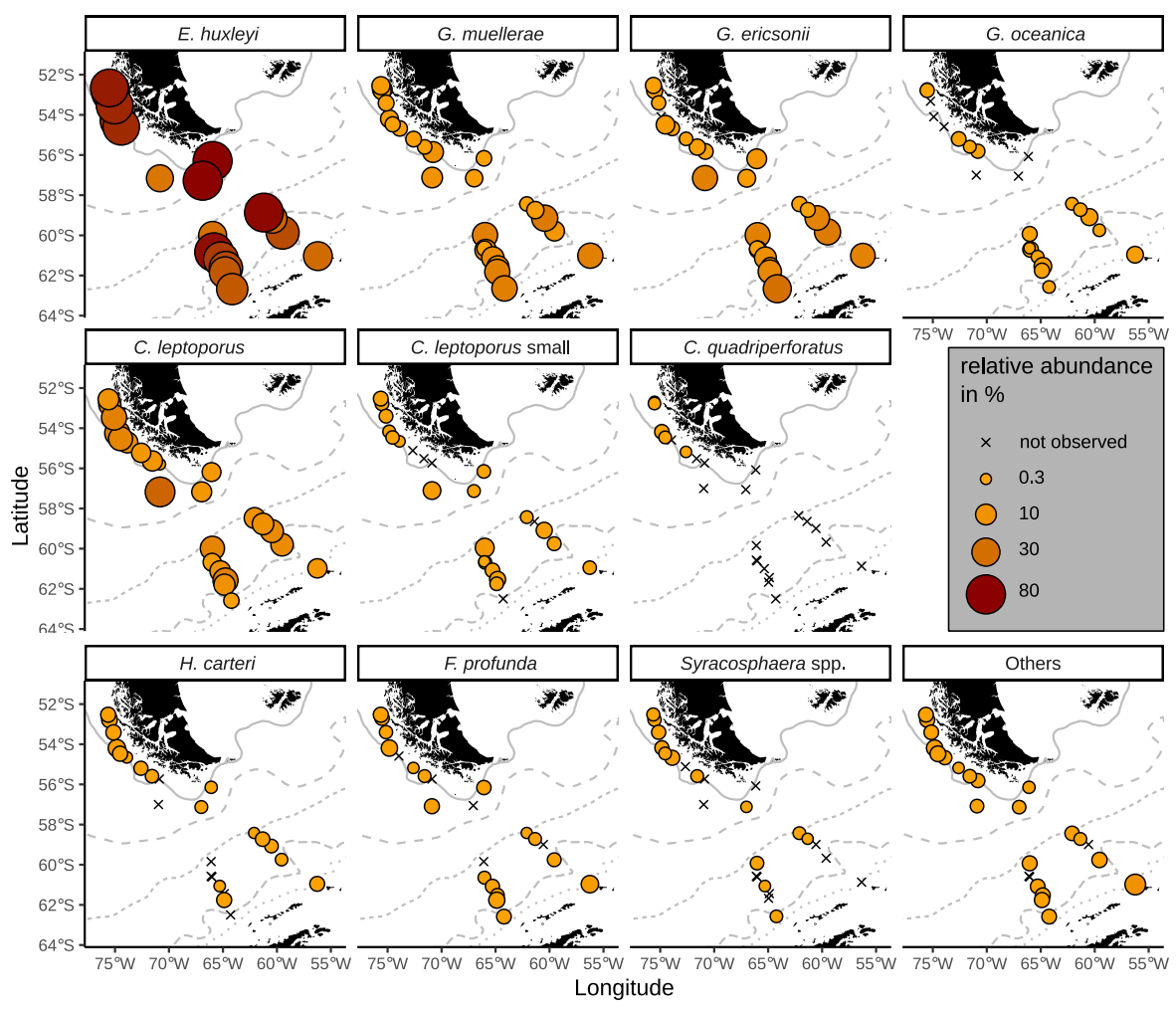

Figure 4. Relative abundances of relevant species in the surface sediments. ACC Fronts from north to south: NB (Northern Boundary), SAF (Subantarctic Front), PF (Polar Front), sACCF (southern ACC Front), SB (Southern Boundary).

\subsection{Cluster and Redundancy Analysis}

We performed Hierarchical Cluster Analysis on the relative species assemblages resulting in two groups (see section 5). Group A consists of samples that stem from water depths above $3.1 \mathrm{~km}$ from the SAZ and AZ. Group B consists of samples that are either from the $\mathrm{SZ}+\mathrm{CZ}$, or from the $\mathrm{AZ}$ below or just above $3.1 \mathrm{~km}$, and one sample from the $\mathrm{SAZ}$ far below $3.1 \mathrm{~km}$.

Additional to sample depth, we assessed possible further drivers of the assemblage distributions using RDA. Constraining the surface sediment species assemblages to sample depth, $\mathrm{CO}_{3}$ as representative variable for the carbon system at sample depth, and the MLD, PAR, temperature, phosphate and salinity at $10 \mathrm{~m}$ water depth, results in a significant $(\mathrm{p}=0.0004)$ RDA and a significant first axis $\left(\mathrm{p}_{\mathrm{RDA} 1}=0.0005\right)$ at 10000 permutations. In line with the previous findings, highest significance is found for the surface sediment samples water depth $(\mathrm{p}=0.0011)$. Further important drivers are PAR at $10 \mathrm{~m}(\mathrm{p}=0.0222)$, salinity at $10 \mathrm{~m}(\mathrm{p}=0.0269)$, and phosphate at $10 \mathrm{~m}(\mathrm{p}=0.0314)$. Depending on the significance threshold, temperature at $10 \mathrm{~m}$ could also be considered relevant ( $\mathrm{p}=0.0541$ ). These environmental parameters are negatively correlated to the first RDA axis (RDA1) with scores of -0.76 (sample depth), -0.59 (PAR), -0.67 (salinity), -0.63 (phosphate) and 0.51 (temperature). 
https://doi.org/10.5194/bg-2021-105

Preprint. Discussion started: 23 April 2021

(c) Author(s) 2021. CC BY 4.0 License.

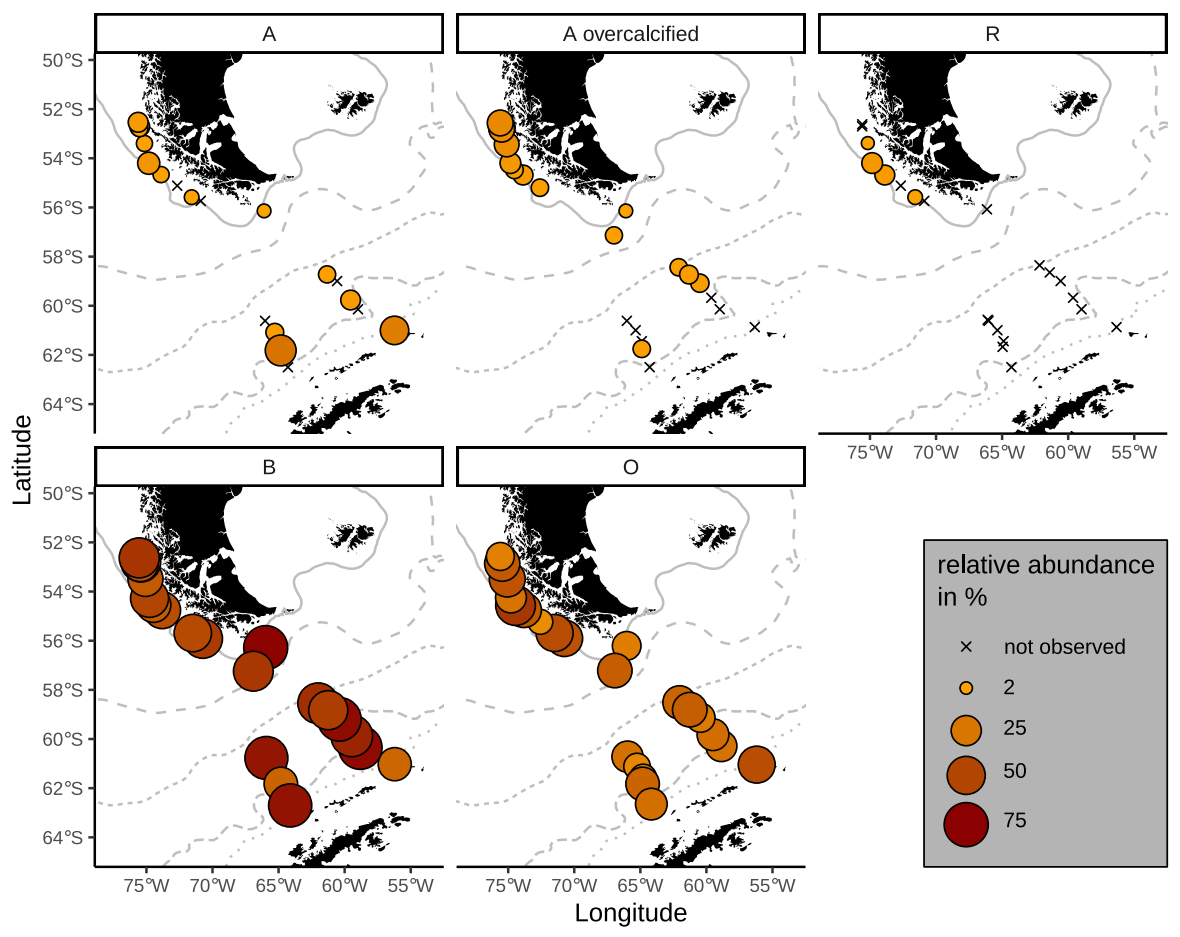

Figure 5. Relative proportions of E. huxleyi morphotypes. Top: Morphogroup A, bottom: Morphogroup B. Crosses mark samples where the respective morphotype was not observed. ACC Fronts from north to south: NB (Northern Boundary), SAF (Subantarctic Front), PF (Polar Front), sACCF (southern ACC Front), SB (Southern Boundary).

\subsection{Emiliania huxleyi morphotypes}

Emiliania huxleyi coccoliths belonging to morphotypes A, A overcalcified and R are mainly found in the SAZ (Figure 5). Morphotype A is found in very few numbers across all zones, making up from 1 to $27 \%$ of the identified E. huxleyi morphotypes. In particular, morphotype A overcalcified is abundant in the northernmost samples along the Chilean margin (reaching up to ca. $15 \%$ ) with decreasing numbers towards the south (ca. $5 \%$ ). Few coccoliths of E. huxleyi morphotype A overcalcified were identified in some samples in the AZ, but they are absent from $\mathrm{SZ}+\mathrm{CZ}$ locations. Morphotype $\mathrm{R}$ is restricted to samples in the SAZ and it is present only in low relative abundances (1-7\%). Morphogroup B is dominating the E. huxleyi coccolith assemblages in the studied surface sediment samples, with ca. 13 to $56 \%$ of the coccoliths belonging to morphotype $\mathrm{O}$ and ca. 2 to $77 \%$ to morphotype B/C. Morphotype $\mathrm{O}$ was found to be slightly more abundant in the SAZ, while morphotype B/C was more prominent in the AZ. 
https://doi.org/10.5194/bg-2021-105

Preprint. Discussion started: 23 April 2021

(c) Author(s) 2021. CC BY 4.0 License.

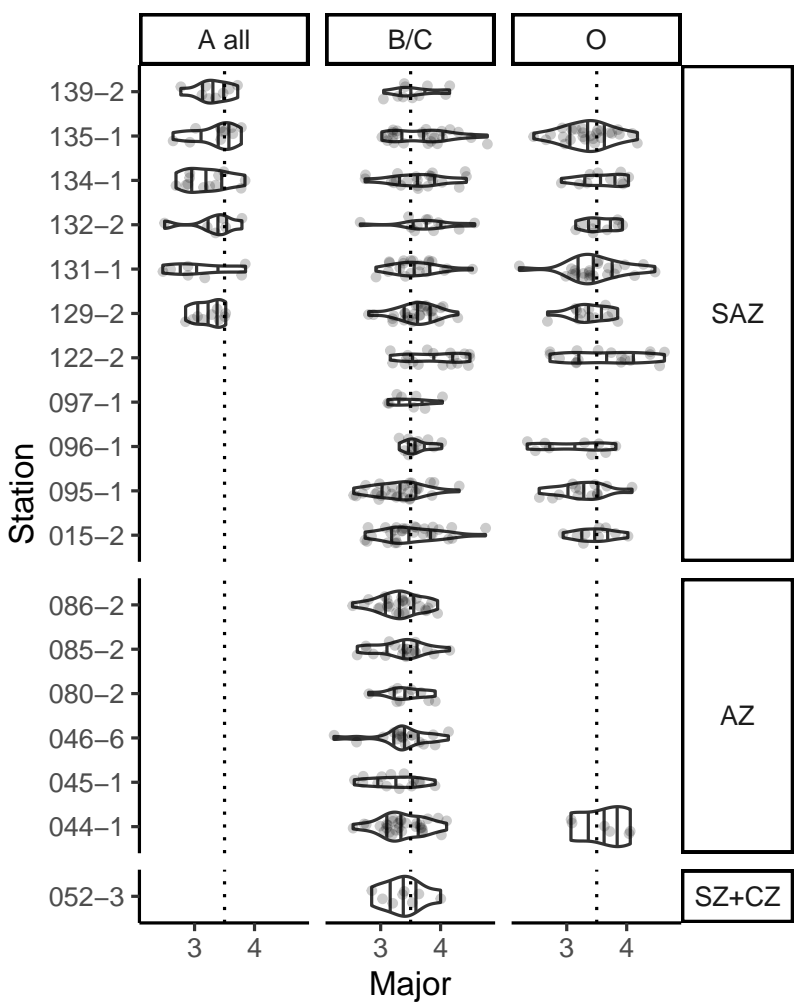

Figure 6. Coccolith length distribution of E. huxleyi morphotypes from north to south. Morphotypes A and A overcalcified were merged. Gray dots show the actual measurements. Vertical dotted line is shown at $3.5 \mu \mathrm{m}$ for visual guidance. Data only shown for stations with more than 5 measurements.

\subsection{Emiliania huxleyi biometries and mass estimates}

Emiliania huxleyi coccoliths belonging to the morphogroup B predominate in the study area, showing a size variation of Type $\mathrm{B} / \mathrm{C}$ coccoliths from $2.22 \mu \mathrm{m}$ to $4.78 \mu \mathrm{m}$ and of Type $\mathrm{O}$ coccoliths from $2.21 \mu \mathrm{m}$ to $4.63 \mu \mathrm{m}$ (Figure 6 ). Coccoliths belonging to morphotypes A and A overcalcified were only measured in the SAZ with lengths of 2.47 to $3.85 \mu \mathrm{m}$. Within morphotype $\mathrm{B} / \mathrm{C}$ there is an decreasing size trend from north to south, with maximum lengths of $4.78 \mu \mathrm{m}$ in the $\mathrm{SAZ}, 4.15 \mu \mathrm{m}$ in the $\mathrm{AZ}$ and $4 \mu \mathrm{m}$ in the SZ+CZ. Morphotype O reaches comparable lengths of up to $4.63 \mu \mathrm{m}$ in the SAZ.

Overall, the number of coccoliths in morphogroup B (Types B/C and O) longer than $4 \mu \mathrm{m}$ decreases from 3 to $50 \%$ in the SAZ to up to $6 \%$ in the AZ, while the number of coccoliths smaller than $3.5 \mu \mathrm{m}$ increases from 16 to $72 \%$ in the SAZ to 60 to $70 \%$ in the AZ. Coccoliths in morphogroup A (Types A and A overcalcified were measured, but morphotype R was not) are considerably smaller than the coccoliths in morphogroup B.

Mass estimates after Beuvier et al. (2019) and Young and Ziveri (2000) (see subsection 3.4) based on the morphometrical measurements of $E$. huxleyi coccoliths are comparable (Equation 4 after Beuvier et al., 2019 and 5 after Young and Ziveri, 
https://doi.org/10.5194/bg-2021-105

Preprint. Discussion started: 23 April 2021

(c) Author(s) 2021. CC BY 4.0 License.

Table 3. Summary of mass estimations using two different calculation methods: Equation 4 after Beuvier et al. (2019) and Equation 5 after Young and Ziveri (2000). All measurements in $\mu \mathrm{m}$.

\begin{tabular}{llrrrrrr}
\hline \multirow{2}{*}{ method } & frontal zone & $\mathrm{n}$ & mean & median & $\min$ & $\max$ & range \\
\hline \multirow{2}{*}{4} & SAZ & 389 & 2.28 & 2.01 & 0.02 & 8.45 & 8.42 \\
& AZ & 124 & 1.63 & 1.49 & 0.55 & 4.32 & 3.77 \\
& SZ+CZ & 8 & 1.74 & 1.48 & 1.04 & 2.62 & 1.57 \\
\hline \multirow{2}{*}{5} & all & 521 & 2.12 & 1.77 & 0.02 & 8.45 & 8.42 \\
\hline & SAZ & 389 & 2.36 & 2.15 & 0.44 & 6.14 & 5.70 \\
& AZ & 124 & 2.09 & 2.04 & 0.59 & 3.87 & 3.28 \\
& SZ+CZ & 8 & 2.15 & 2.09 & 1.25 & 3.47 & 2.21 \\
\hline & all & 521 & 2.29 & 2.11 & 0.44 & 6.14 & 5.70
\end{tabular}

310 2000) with an overall mean of $2.12 \mathrm{pg}$ (Equation 4) and $2.29 \mathrm{pg}$ (Equation 5), respectively (see Table 3 and Figure A2). The mass estimates using the first formula were generally a little lower, although it also yielded maximum mass estimates of $>8 \mathrm{pg}$ for some coccoliths of morphotype $\mathrm{B} / \mathrm{C}$, for which Equation 5 estimates maximum values of up to $6 \mathrm{pg}$. Lowest masses were found for morphotype A coccoliths (ca. 1 - 3 pg) with both formulas. At the same time, Equation 4 largely underestimates the masses of morphotype A overcalcified coccoliths (to mostly under $2 \mathrm{pg}$ ), while Equation 5 estimates masses of 2 - $6 \mathrm{pg}$ for those coccoliths. Highest range in mass were found in the SAZ, with $8.42 \mathrm{pg}$ and $5.7 \mathrm{pg}$, respectively. 
https://doi.org/10.5194/bg-2021-105

Preprint. Discussion started: 23 April 2021

(c) Author(s) 2021. CC BY 4.0 License.

(c) (i)

\section{Interpretation and Discussion}

The surface sediments in our study area are characterized by a striking difference in the total coccoliths abundance, with higher Coc/g sed. along the Chilean margin than south of the PF (Figure 7). In total, 22 species were identified in the surface sediments samples analysed. This is rather surprising because so far only between 8 and a maximum of 15 species have been found in samples located along latitudinal transects crossing the same frontal systems in other sectors of the SO (e.g., Findlay and Giraudeau (2002); Boeckel et al. (2006); Riaux-Gobin et al. (2006); Saavedra-Pellitero et al. (2019)). Fewer species have also been found in comparable sediment settings in the northern North Atlantic (e.g., Baumann et al., 2000).

The high coccolith abundances along the Chilean margin within the SAZ clearly suggests relatively high productivity conditions in the surface water. The species composition, dominated by E. huxleyi, C. leptoporus, and Gephyrocapsa species, agrees well with those of Chilean communities in overlying plankton samples (e.g., Saavedra-Pellitero et al., 2019). Thus, the general good resemblance between (sub-) fossil surface sediment sample and living communities indicate that the regional oceanography plays an important role shaping recent assemblages.

Coccolith abundances in surface sediments south of the PF are lower than at the Chilean margin, but they are still unusually high for this southern latitude (up to $650 \times 10^{6} \mathrm{Coc} / \mathrm{g}$ sed.). As it has often been observed, coccoliths are replaced by diatom valves, which become more abundant southwards (e.g., Cárdenas et al., 2019, see Figure 7). However, a decrease in coccolith diversity is not observed at and south of the PF (see Figure 3). Emiliania huxleyi remains the dominant species together with robust taxa, such as $G$. muellerae and C. leptoporus. In addition, other taxa are selectively enriched here and even species that are not observed in the overlying plankton samples offshore southern Chile and across the DP are recorded in the surface sediment samples. This potentially suggests that other factors than surface-ocean productivity might have affected the species composition in these samples.

Because of the scarcity of coccolith studies in surface sediments across similar latitudinal transects in the SO, the determination of the ecological drivers of the coccolithophore assemblages in this region, and potential implications for paleorecord interpretations have not been extensively explored. In the following sections we will interpret and discuss the potential in-situ and post-depositional factors that may govern the coccolith abundance and species composition in southern high latitudes, with special focus on E. huxleyi and its different morphotypes.

\subsection{Productivity-related distribution on the continental slope offshore southern Chile and comparison with plankton and sediment-trap findings}

The observed high numbers of coccoliths in the surface sediments offshore southern Chile are in good agreement to previously reported higher coccolith accumulation rates off central Chile (Saavedra-Pellitero et al., 2013), an area that is however, influenced by an active coastal upwelling system. The generally high numbers of coccoliths along the Chilean margin within the SAZ also suggest relatively high productivity conditions in the surface waters. For the present study area, elevated nutrient supply via freshwater runoff by precipitation and seasonal glaciers' melting (e.g., Dávila et al., 2002; Saldías et al., 2019), and relatively warm surface water temperatures in the $\mathrm{CHC}$ in comparison to the overall study area are plausible causes for an 
https://doi.org/10.5194/bg-2021-105

Preprint. Discussion started: 23 April 2021

(c) Author(s) 2021. CC BY 4.0 License.

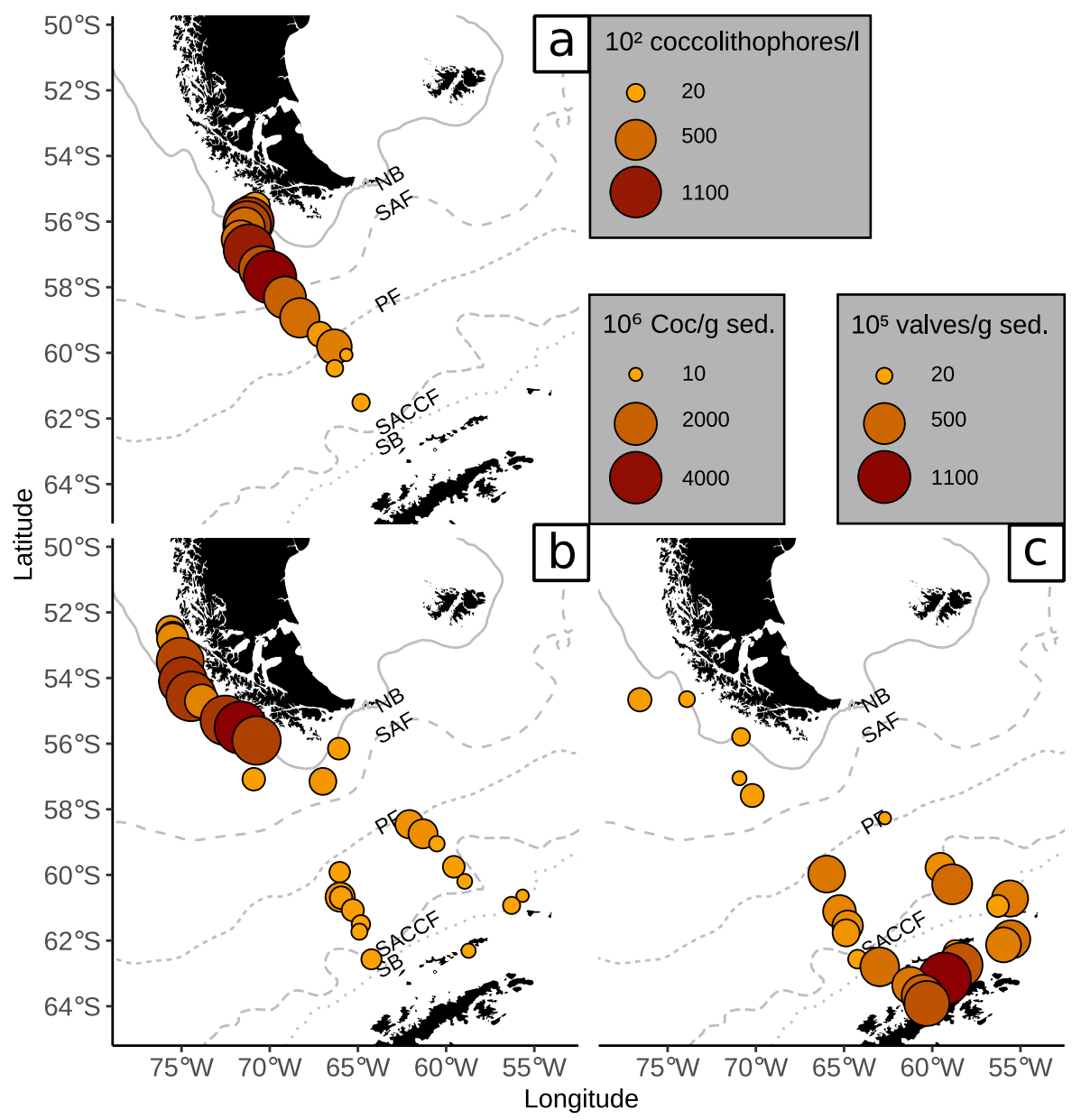

Figure 7. Comparison of (a) coccolithophore counts in plankton samples (mean over all water depths as coccolithophores per $1 * 10^{2}$, Saavedra-Pellitero et al., 2019) with (b) coccolith counts in surface sediments (in Coc/g sed. * $10^{6}$, this study) and (c) diatom valve counts in surface sediments (in valves per g sediment * $10^{5}$, Cárdenas et al., 2019). ACC Fronts from north to south: NB (Northern Boundary), SAF (Subantarctic Front), PF (Polar Front), sACCF (southern ACC Front), SB (Southern Boundary).

elevated coccolithophore production and the related increase in coccolith sedimentation off southern Chile. Slight differences in coccolith abundances between deeper mid slope sediments (between 1.8 and $2.5 \mathrm{~km}$ depth, $>2500 * 10^{6} \mathrm{Coc} / \mathrm{g}$ sed.) and shallower sediments from the upper slope $\left(0.6-1.2 \mathrm{~km}\right.$ depth, $<\max .1000 * 10^{6} \mathrm{Coc} / \mathrm{g}$ sed.) in the SAZ are probably due to dilution of the shallow samples by high sedimentation rates via freshwater runoff near the coast. However, steadily increased coccolithophore abundances and diversity from coastal to oceanic regions as described for areas further to the north (Menschel et al., 2016; von Dassow et al., 2018) may also account for variations in coccolith abundances in the studied slope sediments off southern Chile. 
https://doi.org/10.5194/bg-2021-105

Preprint. Discussion started: 23 April 2021

(c) Author(s) 2021. CC BY 4.0 License.

(c) (i)

The coccolithophore species composition in surface sediments studied here, dominated by E. huxleyi and Gephyrocapsa species, agrees well with assemblages found in nearby surface sediment stations located further north offshore Chile (SaavedraPellitero et al., 2010, 2011) as well as to those found in overlying plankton samples (e.g., Menschel et al., 2016; SaavedraPellitero et al., 2019). Some species are identified in both surface sediment and plankton samples (i.e., E. huxleyi, G. muellerae, C. leptoporus and Syracosphaera spp.) while few other species are only present in plankton samples. Emiliania huxleyi is the dominant species present in all the surface sediment samples from the study area, found even in samples in the $\mathrm{SZ}+\mathrm{CZ}$ and AZ (see Figure 4). This species dominates the coccolithophore communities in the open ocean surface waters of the study area (e.g., Charalampopoulou et al., 2016; Saavedra-Pellitero et al., 2019), but it was also the dominant coccolith species in sediment traps of the SAZ and AZ south of Tasmania (Rigual Hernández et al., 2018, 2020) and of the AZ on the Kerguelen Plateau (Rembauville et al., 2016). Furthermore, it was also the only coccolithophore widely distributed along the fjords and inner channels of southern Patagonia (Díaz-Rosas et al., 2021). Previous studies in the SO have observed a distribution clearly limited up to the extent of the sAACF (Malinverno et al., 2015; Holligan et al., 2010), which was interpreted as a minimum thermal tolerance of $1{ }^{\circ} \mathrm{C}$ for this taxon in the SO. This is supported by culture experiments which found out that temperature was the most important driver controlling both cellular particulate organic and inorganic carbon content in E. huxleyi (Feng et al., 2018). However, differences in the composition of the morphotypes within this species complex may indicate locally adapted populations with genotypes that have very different temperature sensitivities. The more common occurrence of heavily calcified E. huxleyi Types A overcalcified and R offshore Chile (Figure 5) are well in accordance to observations with plankton studies from the study area (e.g., von Dassow et al., 2018; Saavedra-Pellitero et al., 2019), and may indicate an adaptation to the physico-chemical conditions in the CHC. In addition, a similar shift in the morphotype composition of E. huxleyi assemblages towards the morphogroup B in the AZ (Figure 5) along the Patagonian Shelf and in the Australian sector (Poulton et al., 2011; Cubillos et al., 2007) was interpreted as shift in dominance of different ecotypes. This highlights the important role of the variation in E. huxleyi morphotypes on the control of coccolith shape and stresses that any morphometrical information should not be interpreted isolated from morphotypic information.

Calcidiscus leptoporus, G. muellerae and G. ericsonii are common species in the surface sediments off southern Chile (Figure 4). While C. leptoporus reached quite common abundances also in the plankton of the study area up to the PF (SaavedraPellitero et al., 2019), G. muellerae and G. ericsonii have been described mainly further north in the SAZ (Menschel et al., 2016; von Dassow et al., 2018; Saavedra-Pellitero et al., 2019). These species were also secondary components of the coccolith sinking assemblages in sediment traps located in the SAZ south of Tasmania (Rigual Hernández et al., 2020). Calcidiscus leptoporus, is generally known as a species with tendency towards cool waters and moderate to high nutrient-rich environments (Boeckel et al., 2006; Baumann et al., 2016). Gepyrocapsa muellerae has also been observed in cold and nutrient-rich environments characterized by high productivity (Saavedra-Pellitero et al., 2010) and temperate and mesotrophic regions (Boeckel et al., 2006). The species was even found at moderate abundances (up to $36 \%$ of total numbers) south of the Falklands and close to the SAF (Charalampopoulou et al., 2016). Gephyrocapsa ericsonii was linked to cool and fresh surface waters especially in upwelling or frontal mixing zones, for example at the Chilean coast (Saavedra-Pellitero et al., 2010) or at the Argentinean margin, where the Malvinas Current and the SAF transport Antarctic waters northwards (Boeckel et al., 2006). Thus, the common 
https://doi.org/10.5194/bg-2021-105

Preprint. Discussion started: 23 April 2021

(C) Author(s) 2021. CC BY 4.0 License.

abundances of these species in the study area could be explained by their preference for mixed and moderate to high nutrient environments, where high productivity occurs. The slight discrepancy between the continuous presence of C. leptoporus, G. muellerae and G. ericsonii in sediment and their episodic occurrence in plankton could be due to the episodic coccolithophore blooming, which might not have coincided with the timing of the plankton sampling. This finding is supported by the pronounced seasonality in the coccolith fluxes with marked intensifications during the peak blooming season in austral summer (Rigual Hernández et al., 2018, 2020). In this regard, the coccolith content and diversity in surface sediments would represent a smoothed multi-annual signal, being potentially more representative of the conditions in the overlying surface ocean.

Coccolith species occurrence documented in the present SAZ surface sediments is consistent with previous reports on coccolithophore assemblage compositions in the surface waters (Findlay and Giraudeau, 2000; Saavedra-Pellitero et al., 2014; Malinverno et al., 2015; Charalampopoulou et al., 2016), sediment traps (Rigual Hernández et al., 2020) and surface sediments (Findlay and Giraudeau, 2000; Saavedra-Pellitero and Baumann, 2015), and are more diverse than those found in the AZ sediment traps (Rembauville et al., 2016; Rigual Hernández et al., 2018). Thus, the general good agreement between (sub-) fossil sediment sample and living assemblages indicate that the regional oceanography plays an important role shaping the structure of the coccolithophore community offshore Chile and broadly north of the PF.

\subsection{Distribution of coccoliths in the DP}

South of the PF coccolith abundances in surface sediments are strikingly lower than at the Chilean margin, but coccoliths are still relatively common in this area (up to $650 \times 10^{6} \mathrm{Coc} / \mathrm{g}$ sed.). It is also noticeable that a decrease in coccolith diversity is not observed in the present surface sediment samples (Figure 3). Thus, the situation south of the PF contrasts with the rapid decline in diversity and coccolithophore abundance observed in plankton samples in the DP and in other sectors of the SO (e.g., Gravalosa et al., 2008; Saavedra-Pellitero et al., 2014; Malinverno et al., 2015; Charalampopoulou et al., 2016; SaavedraPellitero et al., 2019). At the same time, no analogues were found between the species assemblages of a subset of surface samples and the nearest plankton samples from Saavedra-Pellitero et al. (2019) (see Figure A3). This discrepancy could be explained by the episodic nature of coccolithophore bloom events south of the PF (Balch et al., 2014; Winter et al., 2014), which might not have coincided with the timing of the plankton sampling in the DP, while the sediments record in surface samples averages hundreds or even thousands of years.

Emiliania huxleyi remains the dominant species in the DP, and is - as off southern Chile - accompanied by G. muellerae and C. leptoporus, but also by relatively dissolution resistant taxa such as G. oceanica and F. profunda. While the latter species are selectively enriched here, some other species are not even observed in the overlying plankton samples offshore southern Chile and across the DP. These subordinate taxa found in DP sediments are more typical of lower latitudes where they usually live in warmer surface waters. For example, one of the taxon found in unusual abundances at these high-latitudes is F. profunda, which is a typical subtropical-temperate species that dwells in the lower photic zone and is rarely present in high abundance at latitudes outside $30^{\circ} \mathrm{N}$ and S (Hernández-Almeida et al., 2019). Some of these low-latitude species were found in surface water samples retrieved via the ship's water pump system by Winter et al. (1999) during a cruise in austral autumn 1992 in the Weddell Sea, east of the DP. Species belonging to the genus Syracosphaera were mostly found offshore Chile and in the SAZ, 


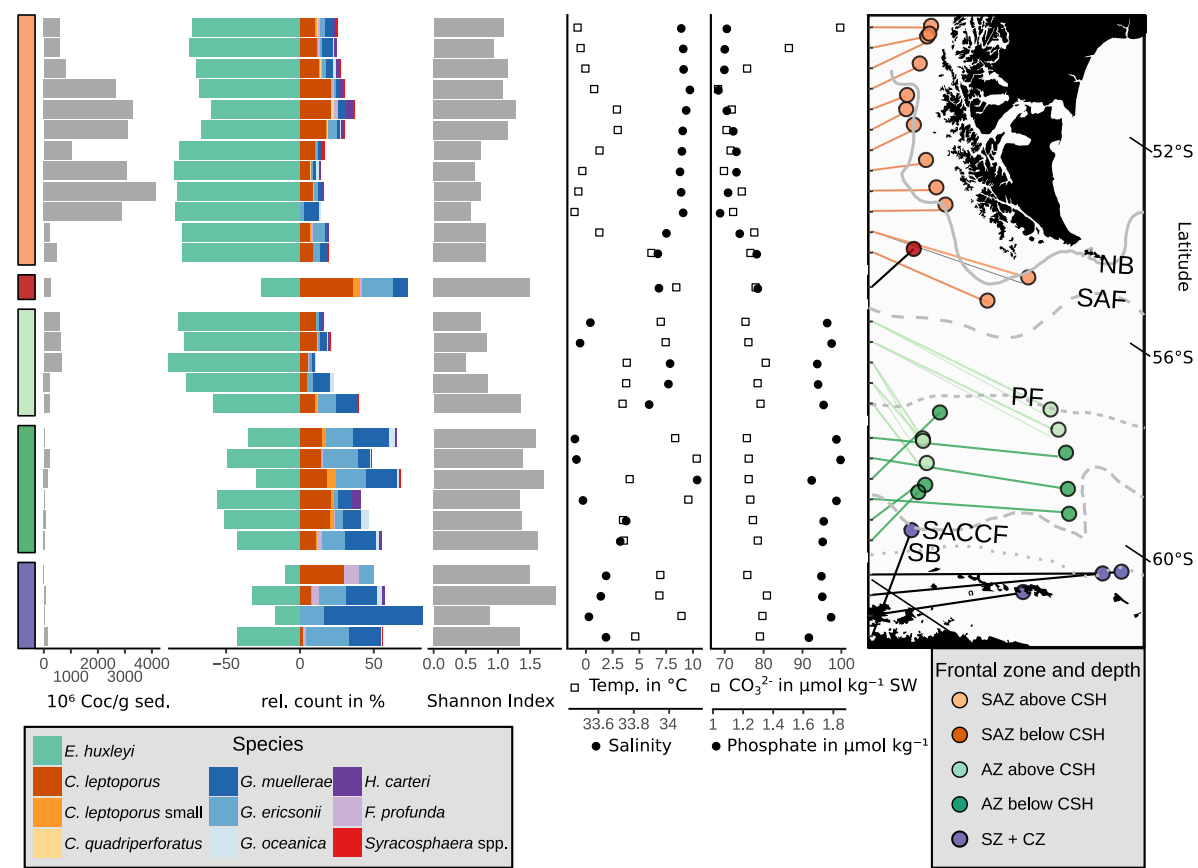

Figure 8. Absolute coccolith abundance, relative abundances of the main Species, Shannon diversity index (see section 3) and environmental parameters at sample depth $\left(\mathrm{CO}_{3}^{2-}\right)$, and at $10 \mathrm{~m}$ water depth (phosphate, salinity, temperature) from north to south related to frontal zone and water depth. Sources of environmental variables as indicated in subsection 3.3. Note that the map is tilted (lines of latitude for reference). ACC Fronts from north to south: NB (Northern Boundary), SAF (Subantarctic Front), PF (Polar Front), sACCF (southern ACC Front), SB (Southern Boundary).

in agreement with previous plankton studies in the DP (Charalampopoulou et al., 2016; Saavedra-Pellitero et al., 2019), but also in the AZ. Although different authors also found taxa of this genus in the SO (e.g., Findlay and Giraudeau, 2000; SaavedraPellitero et al., 2014), it was never observed so close to Antarctica, except by Winter et al. (1999). However, Syracosphaera species have been described from a very similar setting off south-east Greenland (Balestra et al., 2004). There, a quite diverse upper photic zone assemblage dominated by E. huxleyi and Syracosphaera spp. once occurred, despite the harsh environmental conditions with sea surface water covered by ice most of the year. Therefore, the higher diversity in sediment samples may be explained by low-latitude coccolithophores species occasionally thriving south of the PF.

However, although the settling of biogenic material is directly related to surface production and reflects the seasonality of that production (Deuser et al., 1990), the sinking of the particles can strongly be influenced by their drifting due to strong surface and deep currents in the DP. It should be noted that at least the largest part of the coccolith material sinks to the sea floor, incorporated into faecal pellets or in macro-aggregates (marine snow, e.g., Steinmetz, 1994; Honjo, 1976). Factors such as dilution and resuspension processes or drifting of the coccolith material due to strong surface and deep currents may have further influenced the surface sediment assemblage, as it has been observed for other microplankton groups which are 
https://doi.org/10.5194/bg-2021-105

Preprint. Discussion started: 23 April 2021

(c) Author(s) 2021. CC BY 4.0 License.

(c) (i)

deposited in the sea-floor (e.g., van Sebille et al., 2015; Nooteboom et al., 2019, 2020). Nooteboom et al. (2019) showed that bias in microfossil assemblages in surface sediments occur in most oceanic regions and are dependent on current strength and direction, sinking speed and sample depth. The strong ACC flow and frequent eddie formation in the area of the DP (Barré et al., 2011) are likely to influence the sinking pathways of coccoliths. Thus, temperate taxa observed might not be in situ but could have been transported by currents, mostly the CHC, Peru-Chile Countercurrent and the Peru-Chile Undercurrent, which flow southward along the Chilean Margin and which carry relatively warm water masses towards and into the SO and the DP through eddy circulation. These taxa may also originate around Patagonia, the southernmost region of South America, or the Patagonian shelf in the southwesternmost South Atlantic. Patagonia is at least one of the most important sources for terrigenous fine-grained sediments, which is predominantly transported by bottom currents into the deep DP (Wu et al., 2019). The same transport mechanism can also be assumed for similar-sized coccoliths from the southern Patagonian shelf, from where species such as G. muellerae, C. leptoporus and Gephyrocapsa small (G. ericsonii) were described in surface sediments (Rivas et al., 2019). Thus, transportation via surface and deep ocean currents is another factor possibly influencing the surface sediment assemblages south of the PF.

\subsection{Alteration of the coccolith assemblages in the DP}

One of the potential factors that could influence coccolith assemblages in surface sediment samples is the depth at which coccoliths are settled. In order to explore the geographical effect of this variable on our dataset, we performed a hierarchical cluster analysis considering the coccolith relative abundances (Figure 9). The cluster analysis identifies two groups of samples, which belong to different oceanic regions and sample depths. Samples in cluster A are mostly found in the SAZ zone, with sample depths above $3.1 \mathrm{~km}$, while samples in cluster B are mostly located south in the AZ, at depths below $3.1 \mathrm{~km}$. Hence, strongest assemblage dissimilarity between clusters is concomitant with sample depth shallower and deeper as $3.1 \mathrm{~km}$. This pattern is exactly matching the distinction of samples by frontal zone and depth above or below the calcite saturation horizon ( $\mathrm{CSH}$, where the water becomes undersaturated with respect to calcite, i.e., $\Omega$ calcite $=1$, Zeebe, 2012) shown in Figure 8, with the exception of samples PS97/052-3 and 074-1. These samples fall out of line as they are located in the AZ above CSH $(2.8 \mathrm{~km})$, but appear grouped with samples in Cluster B (located below the CSH). Thus, the clustering of the samples located along the DP transect indicates that not only oceanographic variables, but also sample depth, which controls the calcium carbonate preservation, are influencing the composition of the coccolith assemblage, particularly south of the PF.

Based on the clustering findings and considering that other potential factors than only surface-ocean productivity seem to be affecting the coccolith assemblages, we decided to further explore and test the potential influence of the sediment sample depth compared to other environmental variables driving the coccolithophore species composition, with a Redundancy Analysis (RDA). The scores of the surface sediment samples located along RDA1 (which explains almost $68 \%$ of the variance) are separated in two groups which correspond to the two clusters, A and B, identified with the hierarchical analyses. The assemblages located in a more open ocean setting in the SAZ are comparable to those south of the PF (Figure 11). In both regions (southern SAZ and AZ) we found consistent differences in the assemblages in samples above and below $3.1 \mathrm{~km}$ (Figure 11). At depths deeper than $3.1 \mathrm{~km}$, assemblages are characterized by having lower abundances of the relatively fragile $E$. 
https://doi.org/10.5194/bg-2021-105

Preprint. Discussion started: 23 April 2021

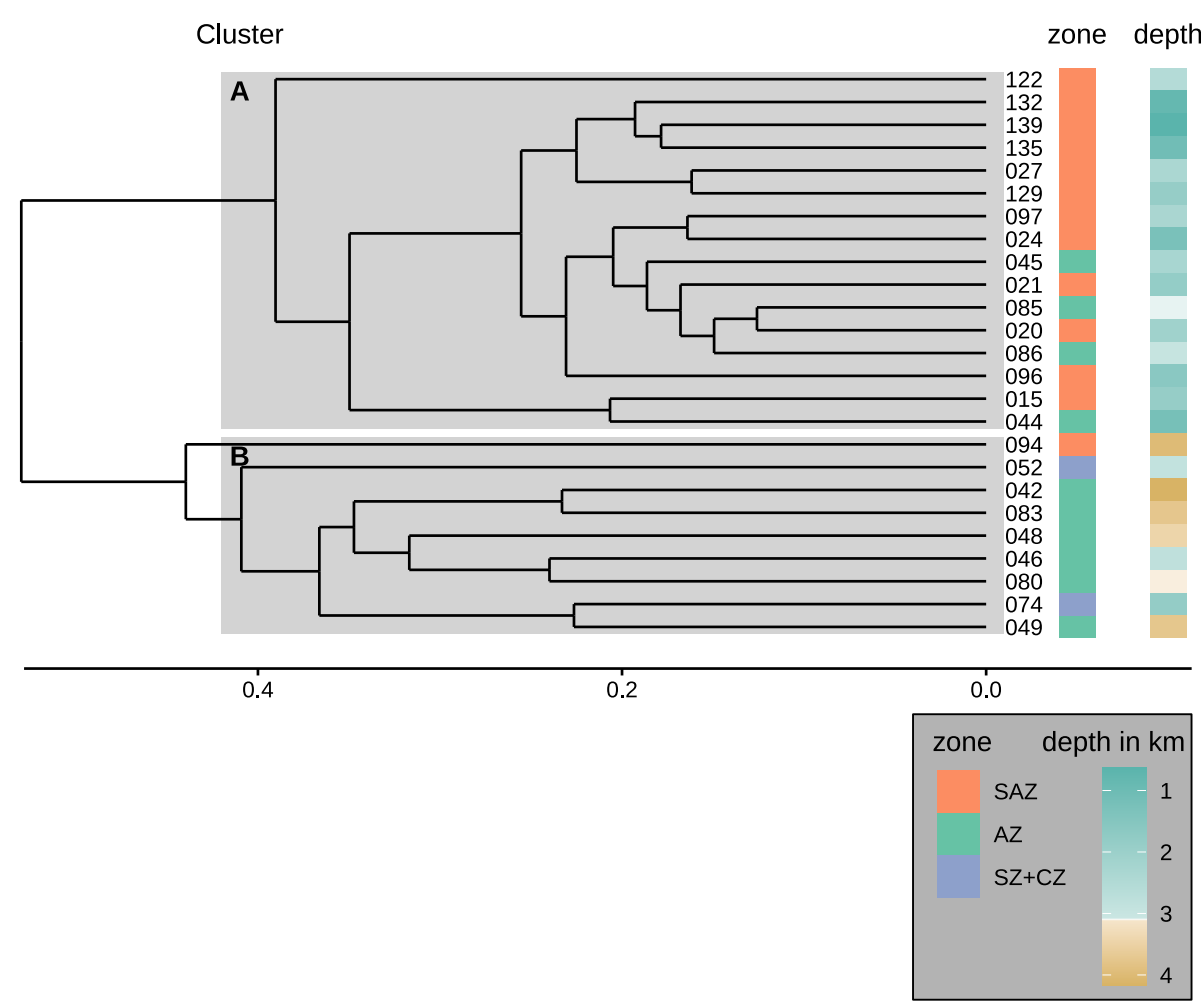

Figure 9. Dendrogram presenting the hierarchical clustering (average linkage) of the species assemblages in the surface sediment samples. The samples were clustered into two groups A and B as suggested by the majority of 30 indices (see section 3). Cluster A consists of all but one sample from the SAZ and some samples from the AZ that stem from water depths above $3.1 \mathrm{~km}$. Cluster B consists of all samples from the AZ that lie below $3.1 \mathrm{~km}$ water depth (except sample PS97/046-6, which stems from a water depth of $2.8 \mathrm{~km}$ ), the two samples from the SZ+CZ and one deep sample from the SAZ (PS97/094-1). Note the frontal zone and the water depth of the respective samples on the right hand side of the dendrogram.

huxleyi and higher abundances of more robust species such as G. muellerae, G. oceanica and C. leptoporus. This feature is even more striking at the deepest sample, PS97/094-1, located at $4 \mathrm{~km}$ water depth in the SAZ, in which the proportion of $E$. huxleyi compared to C. leptoporus and gephyrocapsids is even smaller (Figure 11). Furthermore, the lack of other small, more delicate species than Syracosphaera spp. (e.g., Ophiaster spp., Calciopappus caudatus, Papposphaera sp., Pappomonas sp., Wigwamma antarctica, etc., that were found in the plankton Saavedra-Pellitero et al., 2019) can be attributed to selective dissolution through mechanical destruction when grazed by zooplankton or to dissolution when sinking through the water column (Young et al., 2005).

Based on these observations as well as on the clustering and RDA results, we suggest that carbonate preservation is influencing the species composition at greater depth north and south of the PF. This is supported by the Calcidiscus leptoporus - Emiliania huxleyi Dissolution Index (CEX), an indicator for dissolution processes in coccolith assemblages (Dittert et al., 
https://doi.org/10.5194/bg-2021-105

Preprint. Discussion started: 23 April 2021

(C) Author(s) 2021. CC BY 4.0 License.

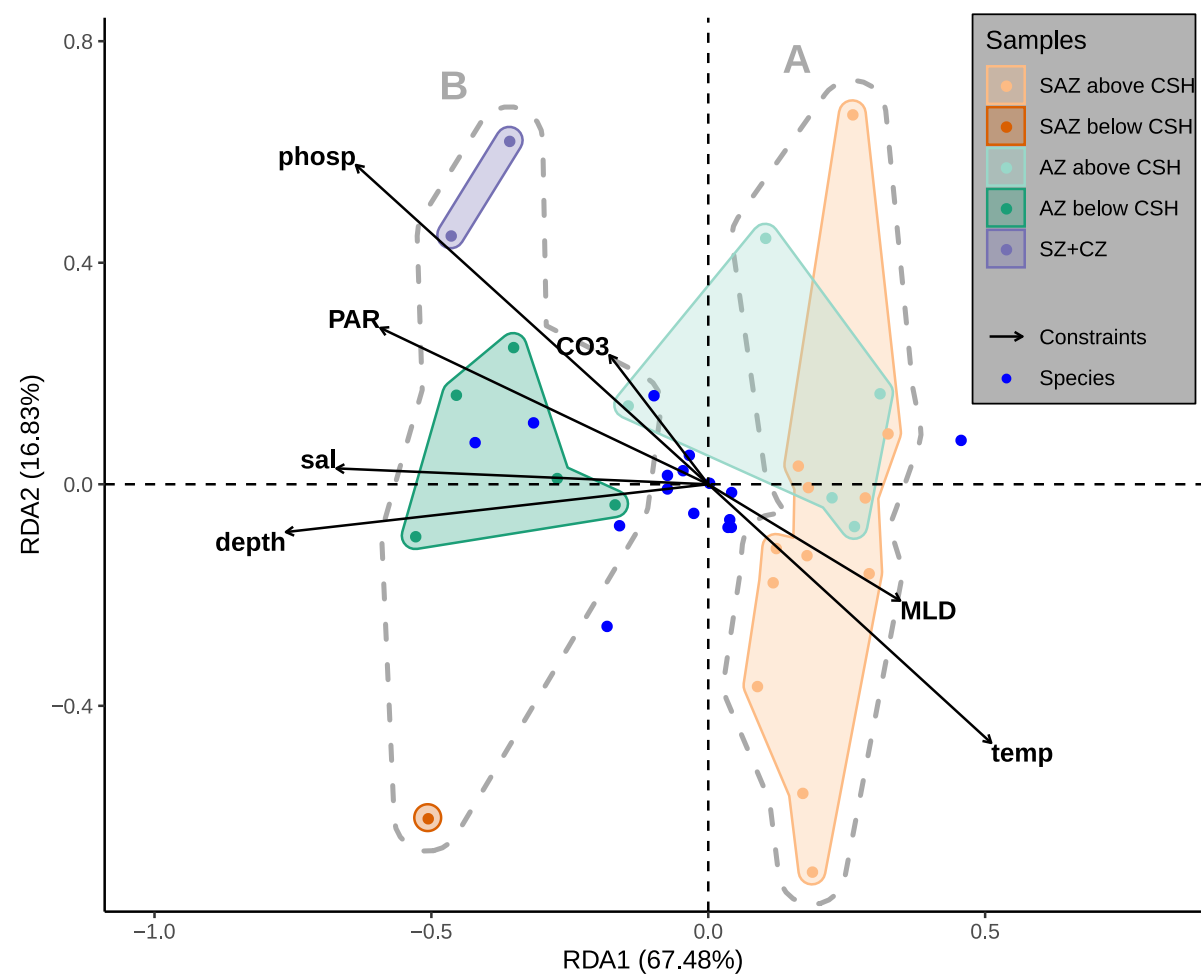

Figure 10. Redundancy analysis based on Hellinger distances (tb-RDA) with an explained variation in species composition by the input environmental variables (adjusted $\mathrm{R}^{2}$ ) of $38.3 \%$. Biplot of the first two RDA axes explaining $84.3 \%$ of the variance between the environmental parameters (black arrows), the species (blue dots) and the samples (coloured dots). Gray dashed hulls outline the clusters (A and B) from the hierarchical cluster analysis, coloured hulls outline the samples from different frontal zones and above or below a depth of $3.1 \mathrm{~km}$. Considered explaining variables are sample depth (depth), mixed layer depth (MLD), temperature (temp), salinity (sal), phosphate (phosp) and photosynthetic available radiation (mean from december to february, PAR) at $10 \mathrm{~m}$ water depth and $\mathrm{CO}_{3}^{2-}\left(\mathrm{CO}^{2}\right)$ at sample depth.

1999). Typically, CEX values below 0.6, indicate selective dissolution of E. huxleyi compared to the more robust C. leptoporus (Dittert et al., 1999). However, in our case, CEX $<0.75$ (below around $3.1 \mathrm{~km}$, see Figure 11) would already suggest preservational issues, coincident with the CSH threshold, which occurs in the DP at a water depth of around 3 to $3.25 \mathrm{~km}$ (Bostock et al., 2013). Below this level, we argue for a selective species-specific dissolution of the delicate $E$. huxleyi in favour of $G$. muellerae dependent on the sample depth.

\subsection{Emiliania huxleyi morphotypes and their calcite mass contributions}

In the surface sediment samples from the DP, the distribution of E. huxleyi reaches unexpectedly high latitudes south of the PF. Except for morphotypes A overcalcified and R, the rest of E. huxleyi morphotypes are present in all bioregional zones. Type A overcalcified is absent in most samples from the $\mathrm{SZ}+\mathrm{CZ}$, and type $\mathrm{R}$ is absent from $\mathrm{AZ}$ and $\mathrm{SZ}+\mathrm{CZ}$. While E. huxleyi morphotypes belonging to morphogroup A are much more abundant in the SAZ, morphotypes within morphogroup B dominate 
https://doi.org/10.5194/bg-2021-105

Preprint. Discussion started: 23 April 2021

(C) Author(s) 2021. CC BY 4.0 License.

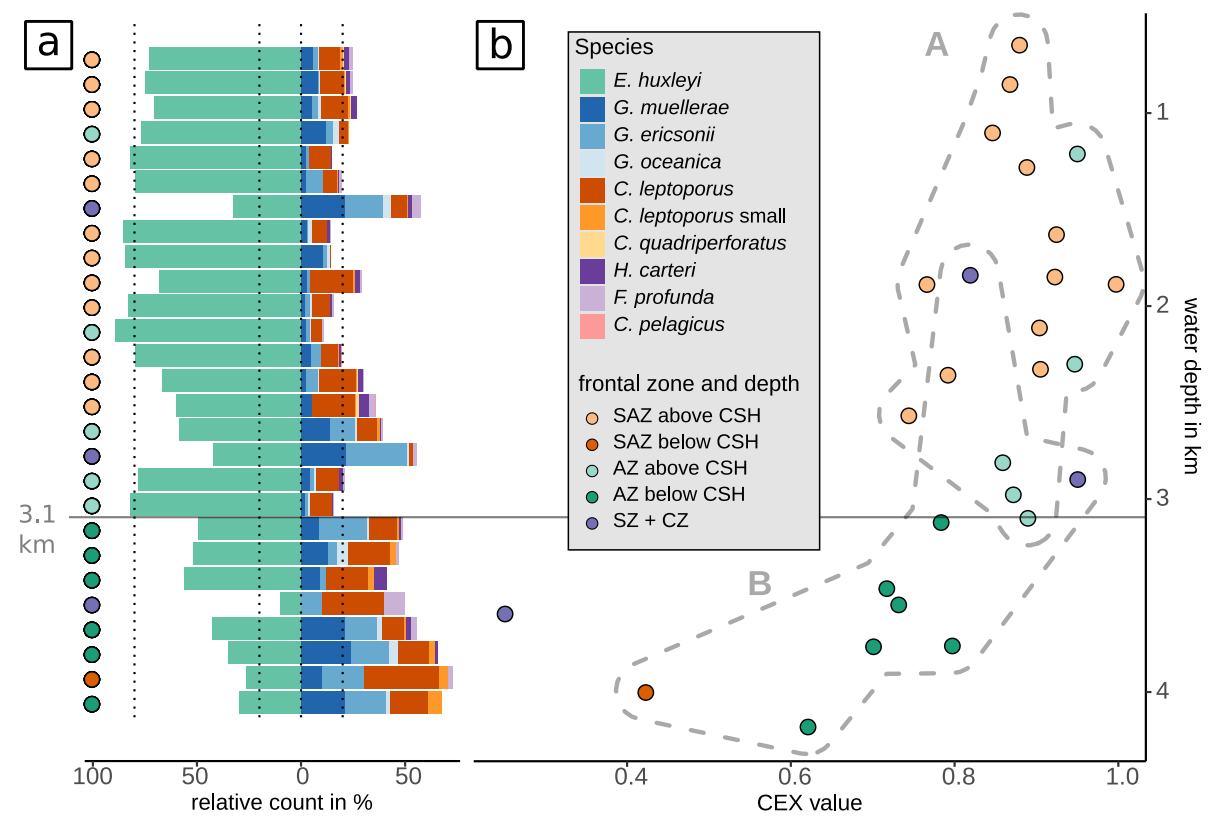

Figure 11. Assemblage changes and indication of dissolution related to water depth: (a) Relative proportions of the delicate E. huxleyi versus the more dissolution resistant Gephyrocapsa and Calcidiscus taxa as well as H. cartei, F. profunda and C. pelagicus. Below $3.1 \mathrm{~km}$ and in the SZ+CZ, species of the genera Gephyrocapsa and Calcidiscus dominate the surface sediment assemblages. (b) Calcidiscus leptoporus Emiliania huxleyi Dissolution Index CEX (Dittert et al., 1999, see Equation 2) against water depth. Dashed outlines indicate the clusters A and B as suggested by cluster analysis, distinguishing clearly the shallower samples above $3.1 \mathrm{~km}$ from deeper samples below $3.1 \mathrm{~km}$ (and from SZ+CZ), with highest CEX values in cluster B. The sample outside the cluster B (PS97/077-1) was not included in hierarchical cluster analysis. Note that the proportion of the dissolution resistant taxa increases below $3.1 \mathrm{~km}$ and that CEX values decrease in parallel. CEX values $<0.75$ are exclusively found for samples below $3.1 \mathrm{~km}$ water depth.

in each of the biogeographic zones. This pattern of dominance is relatively similar to studies of extant communities from the $\mathrm{SO}$, in which E. huxleyi morphotype A is typically restricted to relatively warm waters, north of the PF (usually north of the $\mathrm{SAF}$ ) and morphotype B/C dominates in cooler waters, in some cases even south of the PF (Cubillos et al., 2007; Poulton et al., 2011; Malinverno et al., 2015; Patil et al., 2014; Saavedra-Pellitero and Baumann, 2015; Saavedra-Pellitero et al., 2019) or it is even the only morphotype present (Charalampopoulou et al., 2016; Findlay and Giraudeau, 2000).

In a plankton study along the Patagonian shelf, Poulton et al. (2011) suggested that the morphotypes $\mathrm{A}$ and $\mathrm{B} / \mathrm{C}$ are different ecotypes because of their respective dominance in warmer nutrient-poor and higher calcite saturation state water versus cooler, nutrient rich water with a lower calcite saturation state, respectively. Therefore, shifts in E. huxleyi morphotype assemblage composition seem to correlate to some extent with changes in carbonate system parameters. On the other hand, Beaufort et al. (2011) and von Dassow et al. (2018) occasionally observed in the Eastern South Pacific morphotypes A and R overcalcified dominating in specific stations offshore Chile and Peru, at relative low calcite saturation state surface waters. Even moderately 
https://doi.org/10.5194/bg-2021-105

Preprint. Discussion started: 23 April 2021

(c) Author(s) 2021. CC BY 4.0 License.

(c) (i)

calcified E. huxleyi type A have been observed in the southern Patagonian fjords and channels by Díaz-Rosas et al. (2021), who highlights that the ecological response of this taxon is plastic and that it has high potential for adaptation to different niches.

Within morphotype $\mathrm{B} / \mathrm{C}$, we observed decreasing numbers of large coccoliths $>4 \mu \mathrm{m}$ towards the south, with nearly all occurrences of larger coccoliths in the SAZ (Figure 6). A comparable observation was made by Saavedra-Pellitero and Baumann (2015) in the open south Pacific ocean, where the authors differentiated morphotypes B, B/C and C. The largest type B was found exclusively north of the $\mathrm{PF}$, while the smaller types $\mathrm{B} / \mathrm{C}$ and $\mathrm{C}$ dominated the overall E. huxleyi assemblage. In E. huxleyi morphotype B/C strains from the Arctic Ocean, Saruwatari et al. (2016) observed decreasing coccolith sizes with rising temperatures and decreasing salinities, likely changes to happen in the SO due to the global warming, which would further enhance this signal.

Morphotype $\mathrm{O}$ was identified in all the surface sediment samples and we noted slightly higher relative abundances of this morphotype in the SAZ. Coccoliths with both, plated and open central area, were identified in plankton samples in the DP (Saavedra-Pellitero et al., 2019; Charalampopoulou et al., 2016). This morphotype is, however, also often ignored even in more recent studies or integrated into the B/C morphogroup (e.g., Saavedra-Pellitero et al., 2014; Saavedra-Pellitero and Baumann, 2015; Rigual-Hernández et al., 2020). Up to now, however, it has only been occasionally differentiated in plankton studies and not at all in coccolith assemblages in sediments (Malinverno et al., 2015, 2016; Saavedra-Pellitero et al., 2019). Such a differentiation is possible, although the presence of an open central area might also be an artefact of dissolution, especially in sedimented coccoliths. It is therefore possible, that coccoliths classified as morphotype $\mathrm{O}$ would have been originally morphotype B/C. However, such a differentiation is of importance, since different $E$. huxleyi morphotypes exhibited different sensitivities in regards to seawater carbonate chemistry in cultures (Müller et al., 2015). Therefore, documenting the diversity of E. huxleyi morphotypes, in the SO in general and in the DP in particular, and showing their biogeographical distribution in relation to changing environmental conditions is of critical importance to assess their response to projected environmental change in the SO.

525 The coccolith carbonate mass estimations obtained are in close agreement, with an overall mean mass of $2.12 \mathrm{pg}$ using Equation 4 and of $2.29 \mathrm{pg}$ using Equation 5 (see Table 3). Highest weights were estimated for coccoliths in the SAZ (up to $8.42 \mathrm{pg}$ with Equation 4 or $5.7 \mathrm{pg}$ with Equation 5, Figure 12). Lowest weights are around and below $1 \mathrm{pg}$ across frontal zones independently of the estimation method used. In general, there is a high mass range in the SAZ compared to the other frontal zones, most likely due to the actual E. huxleyi morphotype diversity recorded here. Total mass estimations vary considerably between different studies in the DP, although there is always a common decreasing trend towards the south. Even if absolute values differ due to the various techniques used, the high coccolith mass calculated and the relatively large mass range in the SAZ observed in our study are in agreement with mass estimates based on plankton studies from Saavedra-Pellitero et al. (2019) and Charalampopoulou et al. (2016) (see Figure 12 and subsection 3.2). Saavedra-Pellitero et al. (2019) obtained generally higher mass values using a technique based on circularly polarized light microscopy, and an image processing software, CCalcita (Fuertes et al., 2014) while masses calculated based on length data from Charalampopoulou et al. (2016) were lower (mostly under $2 \mathrm{pg}$ ) using the approach from Young and Ziveri (2000). Combining the decreasing coccolith sizes and carbonate masses observed in this study with predictions of SO warming and freshening due to sea ice melting, and responses of cultured 
https://doi.org/10.5194/bg-2021-105

Preprint. Discussion started: 23 April 2021

(C) Author(s) 2021. CC BY 4.0 License.
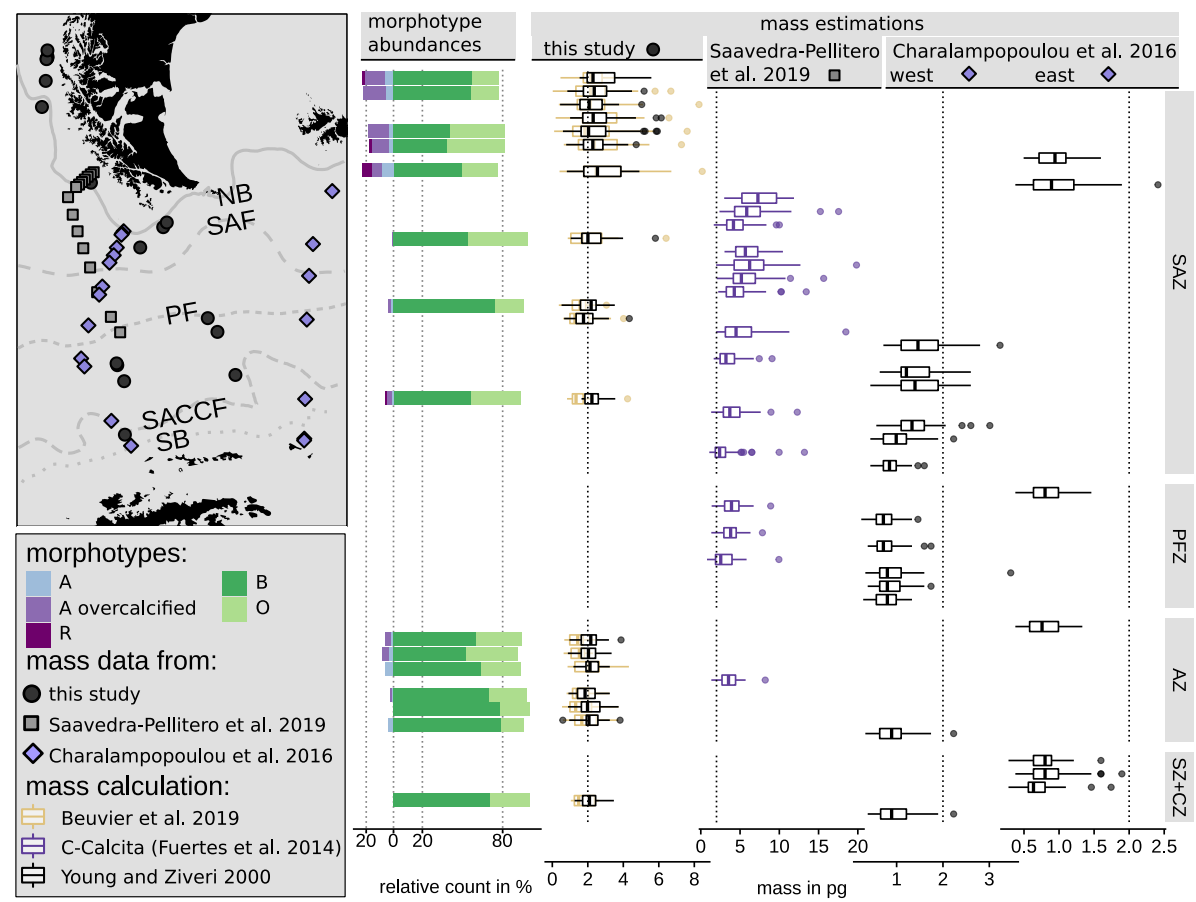

Figure 12. Emiliania huxleyi coccolith morphotype abundances in this study and mass distribution in the DP area comparing three studies: This study (black points) using two mass calculation formulas based on biometries on SEM images (see Equation 4 and 5) from surface sediment samples, Saavedra-Pellitero et al. (2019) (gray rectangles) using C-Calcita software to estimate mass from light microscope images from plankton samples, and Charalampopoulou et al. (2016) (blue diamonds, two transects) using a mass calculation formula (see Equation 5) with a shape factor of 0.015 based on published length measurements from SEM images from plankton samples. Vertical dotted lines depict 0, 20 and $80 \%$ and $2 \mathrm{pg}$, respectively, as visual guidance. ACC Fronts from north to south: NB (Northern Boundary), SAF (Subantarctic Front), PF (Polar Front), sACCF (southern ACC Front), SB (Southern Boundary).

strains to those changes (e.g., Saruwatari et al., 2016), it seems likely that produced coccoliths south of the PF will get smaller and lighter in the future.

\subsection{Implications of the coccolith assemblages in the DP}

Our study suggests that well preserved (sub-) fossil coccolith assemblages in the DP mirror the overlying extant coccolithophore communities which respond to environmental (i.e., physical, chemical and biological) variables, specifically north of the PF. Therefore these assemblages constitute a robust and valuable dataset for qualitative and quantitative calibrations and subsequent reconstructions of surface ocean conditions (i.e. transfer functions and oceanographic/climate models).

The phytoplankton dynamics in the SO is complex, and coccolithophores and diatoms (among other planktonic groups) coexist in this region (e.g., Smith et al., 2017). The coccolithophore diversity and abundance in surface sediment samples located located south of the PF is high compared to plankton studies in the SO (e.g., Mohan et al., 2008; Balch et al., 2011; 
https://doi.org/10.5194/bg-2021-105

Preprint. Discussion started: 23 April 2021

(c) Author(s) 2021. CC BY 4.0 License.

(c) (i)

Malinverno et al., 2016), DP (Charalampopoulou et al., 2016; Saavedra-Pellitero et al., 2019), and surface sediment samples in the Pacific sector of the SO (Saavedra-Pellitero and Baumann, 2015). This demonstrates that calcareous phytoplankton can successfully thrive and be incorporated to the geological record at this latitude and that conditions for their preservation south of the PF are rather variable depending on the region. Although the similarity between living (plankton) coccolithophore communities and fossil surface sediment assemblages is high at the Chilean margin, there are some differences south of the PF. In particular, we observe a southwards enrichment in dissolution resistant species, such as C. leptoporus, at the expense of a decrease of more fragile species, such as E. huxleyi. Combination of statistical techniques (hierarchical clustering and RDA) and dissolution-sensitive indices (CEX) indicate that this shift in the composition is due to the preferential dissolution of calcium carbonate occurring mainly below $3.1 \mathrm{~km}$, which coincides with the depth of the CSH in this region (Bostock et al., 2013). In addition, a proportion of the fossil coccoliths (i.e. temperate taxa) found in sediments in the southernmost samples are most likely non in-situ. Coccolithophores and detached coccoliths are subject to transport from lower latitudes over long distances while settling in the water column, as it has been shown by other microplankton groups, such as planktonic foraminifera or dinoflagellates (e.g., van Sebille et al., 2015; Nooteboom et al., 2019). Therefore, the hydrodynamic and postdepostional processes, which altered the original composition of the coccolith assemblages in some of the DP stations, provide insights into the deep ocean biogeochemistry and hydrography of the study area. These processes distort the original ecological information and limit the potential of coccolith assemblages in surface sediments as surface ocean indicators. These processes need to be taken into account when interpreting downcore coccolith records at high latitudes.

Remote sensing studies over the last decades have detected coccolithophore blooms further north in the North Atlantic linked to anthropogenic-induced climate change (e.g., Smyth et al., 2004; Neukermans et al., 2018). Furthermore, although plankton studies on coccolithophores are mostly limited to the Norwegian-Greenland Seas and the Fram Strait south of the central Arctic Ocean (e.g., Baumann et al., 2000; Dylmer et al., 2015), coccoliths have been found in sediments of the central Arctic Ocean and have intensively been used for stratigraphic purposes (e.g., Gard, 1993; O'Regan et al., 2020). Their occurrences in those sediments were interpreted as an indicator of partly ice-free conditions during at least some summers. Furthermore, by expanding poleward and doubling its areal extent in the northernmost Barents Sea, the occurrence of E. huxleyi attests the ongoing "Atlantification" of the Arctic Ocean (Oziel et al., 2020). The primary driver of the dynamics of this species seem to be, in fact, stronger surface currents, which in turn intrinsically shape the temperature field and frontal structures. In the DP, the occurrence of coccoliths in surface sediments indicate that, despite the lack of observations in the plankton, coccolithophores seem to be continuously present south of the PF or are at least continuously drifted south via eddies during the Holocene. From the available data, however, it is difficult to deduce whether it is an increasing process or an increased shift towards the south. Plankton samples covering the last five decades, however, have shown a gradual poleward expansion of E. huxleyi in the SO (Cubillos et al., 2007; Winter et al., 2013), which currently seems a more permanent member of the summer phytoplankton community south of the PF. The clear dominance of E. huxleyi morphotype B/C (including B, B/C and C according to Saavedra-Pellitero et al., 2019) over morphotype O (with opened central area and with lamella) in plankton samples but not in surface sediments in the DP indicates that this species is highly sensitive to lower calcite saturation state in depth south of the PF. The high numbers of E. huxleyi Type O recorded in the surface sediment samples studied in the AZ and 
https://doi.org/10.5194/bg-2021-105

Preprint. Discussion started: 23 April 2021

(c) Author(s) 2021. CC BY 4.0 License.

(c) (i)

$\mathrm{SZ}+\mathrm{CZ}$ (Figure 5) suggest that some of these specimens could have been originally B/C whose central area would have been affected by dissolution. Other SO living calcifiers, like the pteropod Limacina helicina antarctica, are already experiencing the effects of ocean warming and acidification, as shown by the decrease in shell growth, extensive shell dissolution and malformations (e.g., Bednaršek et al., 2012; Gardner et al., 2018). This loss in carbonate fossils in the geological record obeys to an increase in anthropogenic acidification which is particularly significant in the SO, and it is dissolving the most recent calcium carbonate geological record (Sulpis et al., 2018). Distinguishing E. huxleyi morphotype O in future plankton, sediment trap and surface sediment studies will provide new insights into calcium carbonate dissolution processes due to increasing $\mathrm{CO}_{2}$ dissolved in the SO, which may affect coccolithophores communities either living in the water column or incorporated immediately to the fossil record.

The higher than expected occurrence of coccoliths in surface sediments south of the PF as well as the aforementioned preservational limitations open the possibility that sediment records in sub-polar ice distal regions could have also born more coccoliths during older time intervals. Currently, these type of records in the SO are very scarce, and some of them only show coccoliths during deglaciations or interglacials, which is especially evident for instance during Termination IV or Marine Isotope Stage 11 (e.g., Flores et al., 2003, 2012; Saavedra-Pellitero et al., 2017; Saavedra-Pellitero et al., 2017).

It is imperative to assess the contribution of coccolithophores to changes in present and past processes (Nissen et al., 2018) with in situ SO observations and fossil datasets in order to develop high resolution and well constrained regional and global climate models. Model simulations projecting future coccolithophore growth and calcification in an acidified ocean have also proposed that coccolithophores will expand with increasing $\mathrm{CO}_{2}$ availability, but they will become more lightly calcified, with even "naked"coccolithophores (i.e., without coccoliths) dominating in polar areas (e.g., Krumhardt et al., 2019). To test these future projections, further in situ field observations will be needed during the upcoming years in the already changing polar realm.

\section{Conclusions}

605 Our knowledge about coccolithophore biogeographical distribution in the Southern Ocean is still patchy and rather limited. We tried to fill this gap through the analysis of a series of surface sediment samples offshore Chile and across the Drake Passage (from $52^{\circ} \mathrm{S}$ to $63^{\circ} \mathrm{S}$ ). Based on our data the following conclusions can be drawn:

1. Surface sediment assemblages are very similar to living coccolithophore communities, especially offshore Chile in the Subantarctic Zone. This suggests that the regional oceanography and related physical and chemical parameters play an important role shaping recent assemblages in this region.

2. The coccolith content and diversity in surface sediments north of the Polar Front thus represents a smoothed multi-annual dataset valuable for qualitative and quantitative calibrations (i.e. transfer functions) to accurately reconstruct conditions in the overlying surface ocean.

3. Coccolith abundance and diversity south of the Polar Front are higher compared to other sections of the Southern Ocean.

615 The occurrence of temperate to subtropical species in these surface sediments suggests that other factors than surface-ocean 
https://doi.org/10.5194/bg-2021-105

Preprint. Discussion started: 23 April 2021

(C) Author(s) 2021. CC BY 4.0 License.

(c) (P)

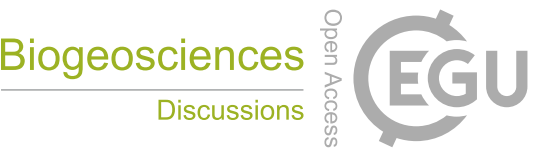

conditions might have affected the species composition in these samples. This could be explained by temperate coccolithophore species occasionally thriving south of the Polar Front, drifted polewards via eddies, or by transport of detached coccoliths via surface and deep oceanic currents.

4. We observe a selective dissolution of less calcified species (Emiliania huxleyi) and enrichment of heavier calcified taxa (e.g., Calcidiscus leptoporus), mainly south of the Polar Front at depths $>3.1 \mathrm{~km}$ in the Drake Passage (CEX dissolution index $<0.75)$.

5. The potential drifting, transport and/or dissolution processes distort the original ecological information and limit the potential of coccolith assemblages as surface ocean indicators south of the Polar Front, but provide valuable information about hydrodynamics and post-depositional processes. This needs to be considered when interpreting downcore coccolith records at high latitudes.

6. Emiliania huxleyi dominates the assemblage, showing a decrease in size from north to south in the morphogroup B as well as reaching its highest masses and mass ranges in the Subantarctic Zone. At the same time, smallest sizes are found in the Subantarcitc Zone due to the occurrence of morphotype A coccoliths.

7. The high abundance of E. huxleyi Type O recorded in the surface sediment samples south of the PF suggests that some of these specimens could have been originally $\mathrm{B} / \mathrm{C}$ morphotypes affected by dissolution. Documenting the diversity of E. huxleyi morphotypes in the SO could provide information about ongoing dissolution of calcium carbonate organisms, either in during their settling in the water column or during their deposition on the sea-floor.

8. The higher than expected abundances of coccoliths in surface sediments south of the Polar Front in the Drake Passage compared to other regions of the Southern Ocean suggest the possibility of further coccolith-rich intervals in in sub-polar ice distal regions both, in recent sedimentary depositions or in the geological record.

Data availability. Supplementary Data has been submitted to PANGAEA Data Archiving \& Publication (under moratorium until the publication of this paper) and is currently in the editorial process.

\section{Appendix A}


https://doi.org/10.5194/bg-2021-105

Preprint. Discussion started: 23 April 2021

(c) Author(s) 2021. CC BY 4.0 License.
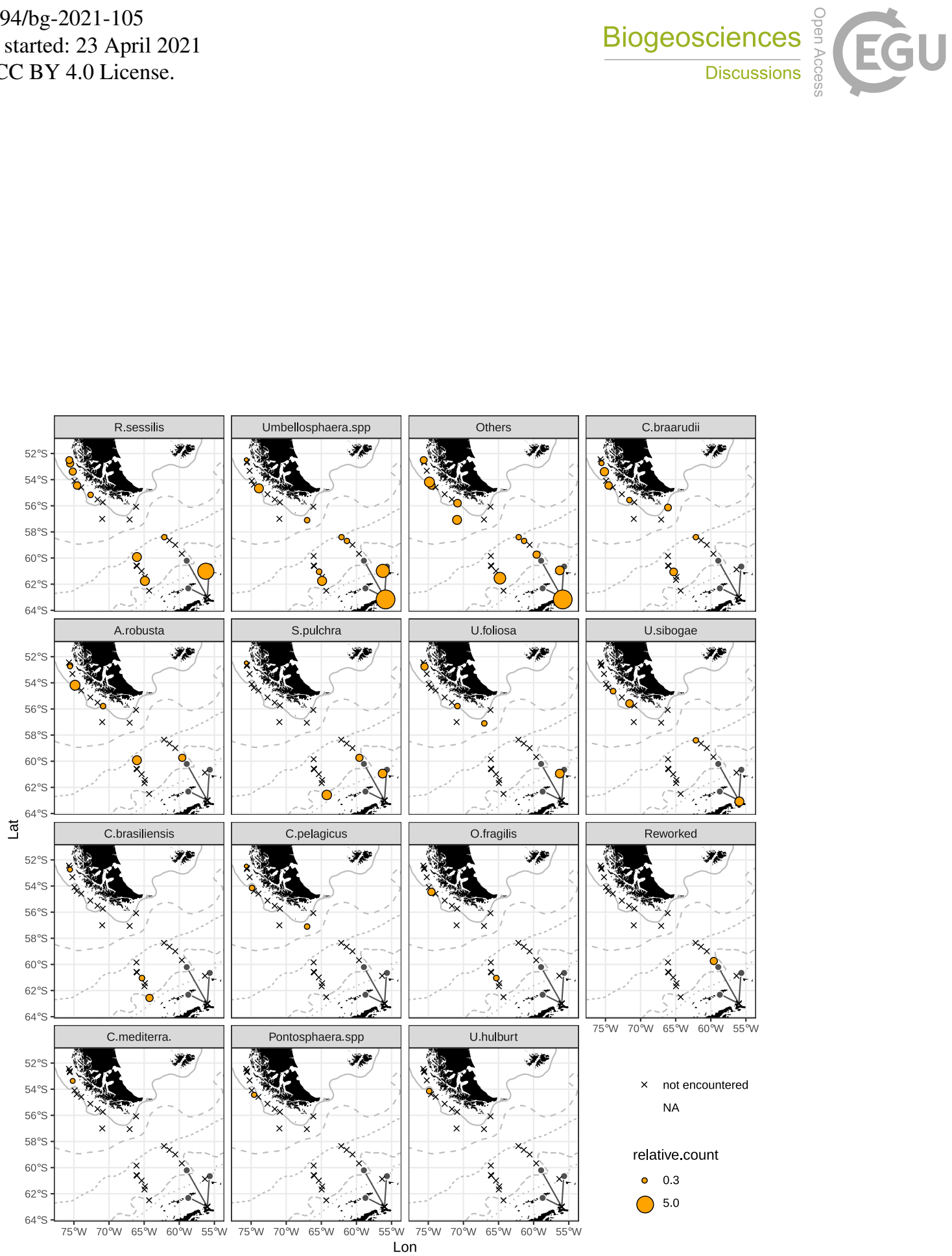

Figure A1. Rare species (abbreviated species are: C.mediterra. $=$ C. mediterranea, U.hulburt $=U$. hulburtiana). Dotted and dahed lines depict the ACC fronts as indicated. From north to south: NB, SAF, PF, sACCF, SB. 
https://doi.org/10.5194/bg-2021-105

Preprint. Discussion started: 23 April 2021

(c) Author(s) 2021. CC BY 4.0 License.

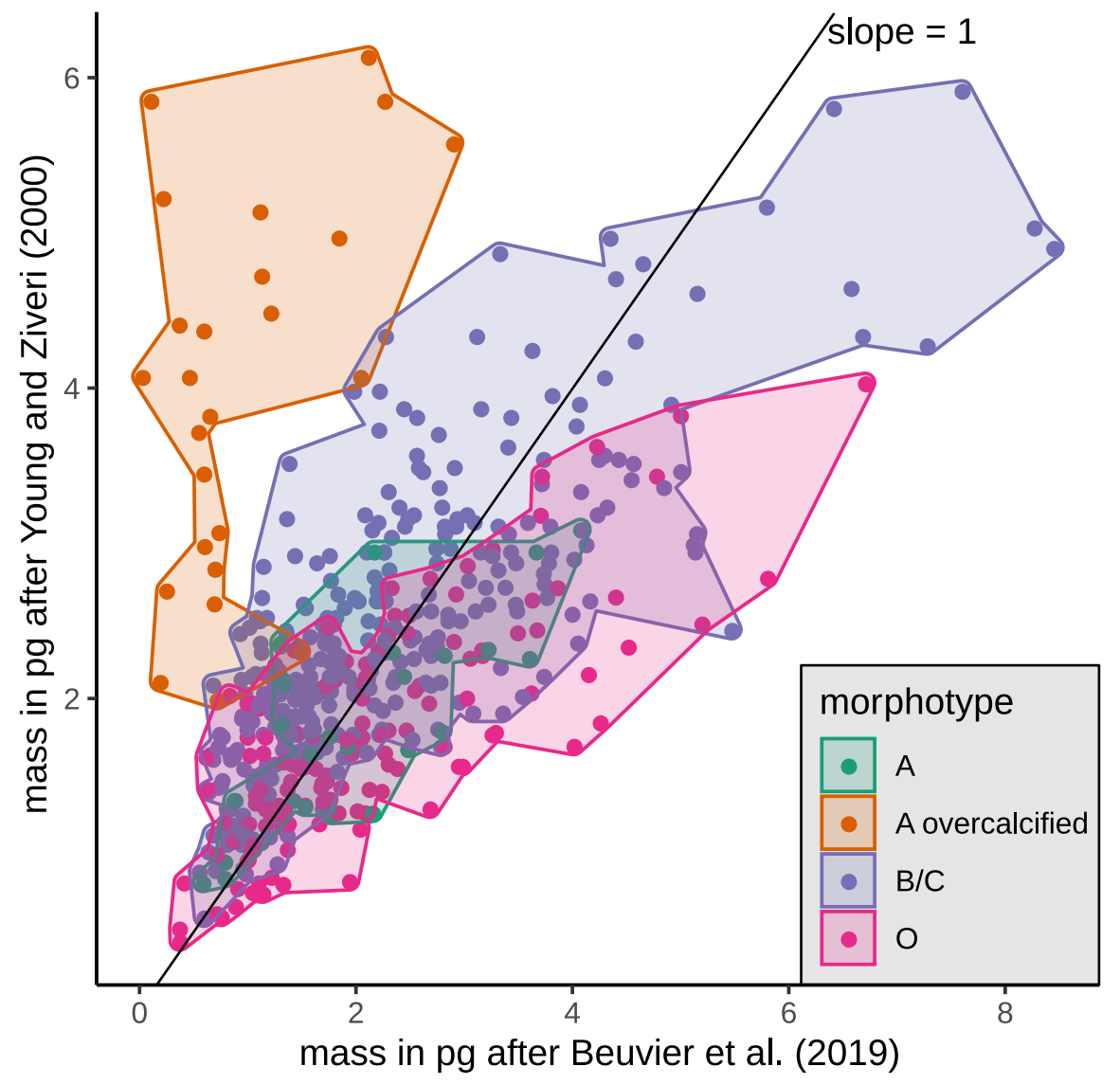

Figure A2. Comparison of mass estimates using two different formulas (Beuvier et al., 2019; Young and Ziveri, 2000). Black line indicates a slope of 1 . 
https://doi.org/10.5194/bg-2021-105

Preprint. Discussion started: 23 April 2021

(c) Author(s) 2021. CC BY 4.0 License.

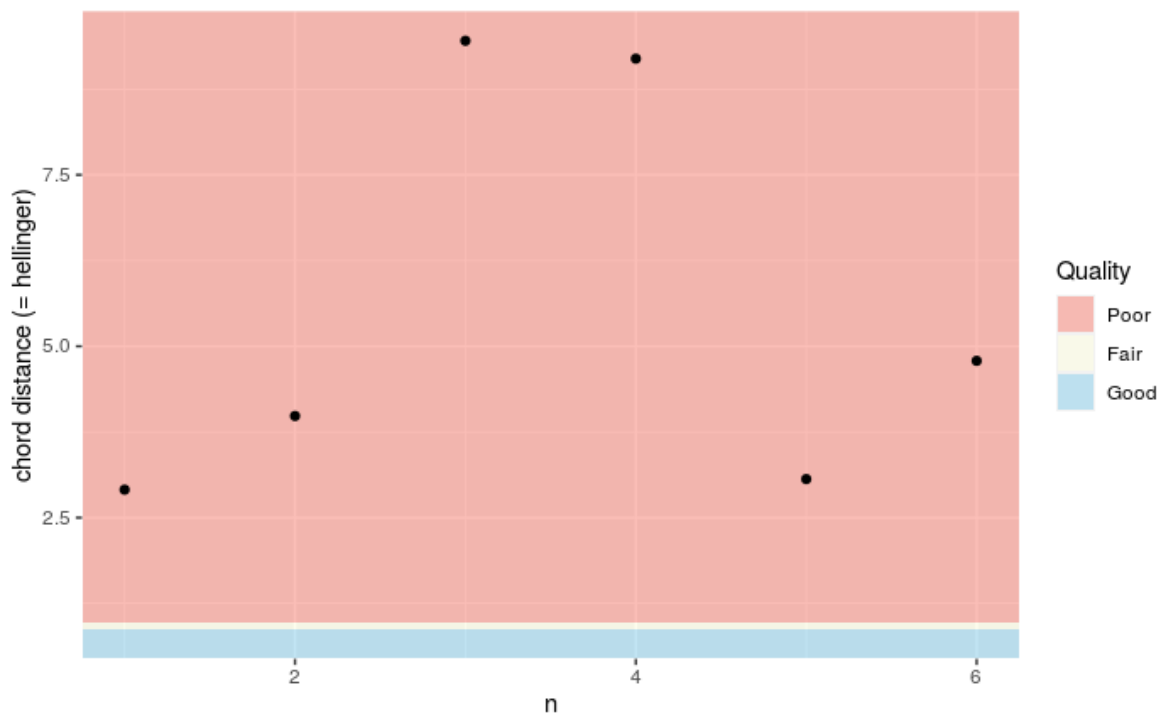

Figure A3. Analogue distance of a subset of the sediment surface samples (PS97/045-1, 044-1, 042-1, 094-1, 015-2, 020-1) to the nearest plankton samples (PS97/043-2, 040-1, 034-2, 016-1, 029-1, Saavedra-Pellitero et al., 2019) provides poor results. Calculated with ggpalaeo version 0.0.0.9005 (Telford, 2019).

Author contributions. NMV carried out the morphometric measurements of E. huxleyi and the mass calculations, the statistical analysis of the assemblage data and the hierarchical clustering of the samples, classified Emiliania huxleyi morphotypes, prepared all the figures and wrote the paper together with all the co-authors. K-HB co-designed the research, prepared samples, did all the assemblage and Emiliania huxleyi morphotypes counts, was involved in the discussion of the data with all co-authors, assisted in the preparation of the first draft of the paper and in the writing of the paper. MS-P co-designed the research, helped with the classification of Emiliania huxleyi morphotypes, participated in the data discussion, and was involved in the writing of the paper. IH-A helped to plan and perform the statistical analysis, provided insights into the interpretation of the statistical results, and was involved in the discussion of the data as well as the writing with the rest of the co-authors.

Competing interests. The authors declare they have no conflicts of interest.

Acknowledgements. This research was supported by the Deutsche Forschungsgemeinschaft (Grant BA 1648/30-1) to K.-H. Baumann, with funding for N. M. Vollmar. M. Saavedra-Pellitero acknowledges the funding from the European Union's Horizon 2020 Research and Innovation Programme under the Marie Sklodowska Curie Grant Agreement No. 799531 and the UKRI funding NE/T009489/1. We thank the master crew and science party of R/V Polarstern Expedition PS97, and we are grateful to F. Lamy and L. Lembke-Jene for providing us the sediment samples required for this study. We sincerely thank Zois Arnopoulos at FB 5 for technical assistance in sample preparation and Emiliania huxleyi image capture. 
https://doi.org/10.5194/bg-2021-105

Preprint. Discussion started: 23 April 2021

(c) Author(s) 2021. CC BY 4.0 License.

(c) (i)

\section{References}

Andruleit, H.: A Filtration Technique for Quantitative Studies of Coccoliths, Micropaleontology, 42, 403-406, https://doi.org/10.2307/1485964, 1996.

Balch, W. M., Drapeau, D. T., Bowler, B. C., Lyczskowski, E., Booth, E. S., and Alley, D.: The Contribution of Coccolithophores to the Optical and Inorganic Carbon Budgets during the Southern Ocean Gas Exchange Experiment: New Evidence in Support of the "Great Calcite Belt" Hypothesis, Journal of Geophysical Research: Oceans, 116, https://doi.org/10.1029/2011JC006941, 2011.

Balch, W. M., Drapeau, D. T., Bowler, B. C., Lyczkowski, E. R., Lubelczyk, L. C., Painter, S. C., and Poulton, A. J.: Surface Biological, Chemical, and Optical Properties of the Patagonian Shelf Coccolithophore Bloom, the Brightest Waters of the Great Calcite Belt, Limnology and Oceanography, 59, 1715-1732, https://doi.org/10.4319/lo.2014.59.5.1715, 2014.

Balch, W. M., Bates, N. R., Lam, P. J., Twining, B. S., Rosengard, S. Z., Bowler, B. C., Drapeau, D. T., Garley, R., Lubelczyk, L. C., Mitchell, C., and Rauschenberg, S.: Factors Regulating the Great Calcite Belt in the Southern Ocean and Its Biogeochemical Significance, Global Biogeochemical Cycles, 30, 1124-1144, https://doi.org/10.1002/2016GB005414, 2016.

Balestra, B., Ziveri, P., Monechi, S., and Troelstra, S.: Coccolithophorids from the Southeast Greenland Margin (Northern North Atlantic): Production, Ecology and the Surface Sediment Record, Micropaleontology, 50, 23-34, https://doi.org/10.2113/50.Suppl_1.23, 2004.

Barré, N., Provost, C., Renault, A., and Sennéchael, N.: Fronts, Meanders and Eddies in Drake Passage during the ANT-XXIII/3 Cruise in January-February 2006: A Satellite Perspective, Deep Sea Research Part II: Topical Studies in Oceanography, 58, 2533-2554, https://doi.org/10.1016/j.dsr2.2011.01.003, 2011.

Baumann, K.-H., Andruleit, H., and Samtleben, C.: Coccolithophores in the Nordic Seas: Comparison of Living Communities with Surface Sediment Assemblages, Deep Sea Research Part II: Topical Studies in Oceanography, 47, 1743-1772, https://doi.org/10.1016/S09670645(00)00005-9, 2000.

Baumann, K.-H., Saavedra-Pellitero, M., Böckel, B., and Ott, C.: Morphometry, Biogeography and Ecology of Calcidiscus and Umbilicosphaera in the South Atlantic, Revue de Micropaléontologie, 59, 239-251, https://doi.org/10.1016/j.revmic.2016.03.001, 2016.

Beaufort, L., Couapel, M., Buchet, N., Claustre, H., and Goyet, C.: Calcite Production by Coccolithophores in the South East Pacific Ocean, Biogeosciences, 5, 1101-1117, https://doi.org/10.5194/bg-5-1101-2008, 2008.

Beaufort, L., Probert, I., de Garidel-Thoron, T., Bendif, E. M., Ruiz-Pino, D., Metzl, N., Goyet, C., Buchet, N., Coupel, P., Grelaud, M., Rost, B., Rickaby, R. E. M., and de Vargas, C.: Sensitivity of Coccolithophores to Carbonate Chemistry and Ocean Acidification, Nature, 476, 80-83, https://doi.org/10.1038/nature10295, 2011.

Bednaršek, N., Tarling, G. A., Bakker, D. C. E., Fielding, S., Jones, E. M., Venables, H. J., Ward, P., Kuzirian, A., Lézé, B., Feely, R. A., and Murphy, E. J.: Extensive Dissolution of Live Pteropods in the Southern Ocean, Nature Geoscience, 5, 881-885, https://doi.org/10.1038/ngeo1635, 2012.

Beuvier, T., Probert, I., Beaufort, L., Suchéras-Marx, B., Chushkin, Y., Zontone, F., and Gibaud, A.: X-Ray Nanotomography of Coccolithophores Reveals That Coccolith Mass and Segment Number Correlate with Grid Size, Nature Communications, 10, 1-8, https://doi.org/10.1038/s41467-019-08635-x, 2019.

Blanco-Ameijeiras, S., Lebrato, M., M. Stoll, H., Iglesias-Rodriguez, D., Müller, M., Méndez Vicente, A., and Oschlies, A.: Phenotypic Variability in the Coccolithophore Emiliania Huxleyi, PLOS ONE, 11, e0157 697, https://doi.org/10.1371/journal.pone.0157697, 2016. 
https://doi.org/10.5194/bg-2021-105

Preprint. Discussion started: 23 April 2021

(c) Author(s) 2021. CC BY 4.0 License.

\section{(c) (1)}

Boeckel, B., Baumann, K.-H., Henrich, R., and Kinkel, H.: Coccolith Distribution Patterns in South Atlantic and Southern Ocean Surface Sediments in Relation to Environmental Gradients, Deep Sea Research Part I: Oceanographic Research Papers, 53, 1073-1099, https://doi.org/10.1016/j.dsr.2005.11.006, 2006.

Bostock, H. C., Mikaloff Fletcher, S. E., and Williams, M. J. M.: Estimating Carbonate Parameters from Hydrographic Data for the Intermediate and Deep Waters of the Southern Hemisphere Oceans, Biogeosciences Discussions, 10, 6225-6257, https://doi.org/10.5194/bgd-106225-2013, 2013.

Buiteveld, H.: A Model for Calculation of Diffuse Light Attenuation (PAR) and Secchi Depth, Netherlands Journal of Aquatic Ecology, 29, 55-65, https://doi.org/10.1007/BF02061789, 1995.

Caniupán, A. M., Lamy, F., Lange, C. B., Kaiser, J., Arz, H. W., Kilian, R., Urrea, O. B., Aracena, C., Hebbeln, D., Kissel, C., Laj, C., Mollenhauer, G., and Tiedemann, R.: Figure 2. Sedimentation Rate and Calculated Sea Surface Temperature of Sediment Core MD073128, https://doi.org/10.1594/PANGAEA.771859, 2011a.

Caniupán, M., Lamy, F., Lange, C. B., Kaiser, J., Arz, H., Kilian, R., Urrea, O. B., Aracena, C., Hebbeln, D., Kissel, C., Laj, C., Mollenhauer, G., and Tiedemann, R.: Millennial-Scale Sea Surface Temperature and Patagonian Ice Sheet Changes off Southernmost Chile (53 ${ }^{\circ}$ S) over the Past 60 Kyr, Paleoceanography, 26, https://doi.org/10.1029/2010PA002049, 2011b.

Cárdenas, P., Lange, C. B., Vernet, M., Esper, O., Srain, B., Vorrath, M.-E., Ehrhardt, S., Müller, J., Kuhn, G., Arz, H. W., Lembke-Jene, L., and Lamy, F.: Biogeochemical Proxies and Diatoms in Surface Sediments across the Drake Passage Reflect Oceanic Domains and Frontal Systems in the Region, Progress in Oceanography, 174, 72-88, https://doi.org/10.1016/j.pocean.2018.10.004, 2019.

Chaigneau, A.: Surface Circulation and Fronts of the South Pacific Ocean, East of $120^{\circ} \mathrm{W}$, Geophysical Research Letters, 32, L08605, https://doi.org/10.1029/2004GL022070, 2005.

Chapman, C. C., Lea, M.-A., Meyer, A., Sallée, J.-B., and Hindell, M.: Defining Southern Ocean Fronts and Their Influence on Biological and Physical Processes in a Changing Climate, Nature Climate Change, 10, 209-219, https://doi.org/10.1038/s41558-020-0705-4, 2020.

Charalampopoulou, A.: Coccolithophores in High Latitude and Polar Regions: Relationships between Community Composition, Calcification and Environmental Factors, Doctor of Philosophy, University of Southampton, Southampton, 2011.

Charalampopoulou, A., Poulton, A. J., Bakker, D. C. E., Lucas, M. I., Stinchcombe, M. C., and Tyrrell, T.: Environmental Drivers of Coccolithophore Abundance and Calcification across Drake Passage (Southern Ocean), Biogeosciences, 13, 5917-5935, https://doi.org/10.5194/bg-13-5917-2016, 2016.

Charrad, M., Ghazzali, N., Boiteau, V., and Niknafs, A.: NbClust : An R Package for Determining the Relevant Number of Clusters in a Data Set, Journal of Statistical Software, 61, https://doi.org/10.18637/jss.v061.i06, 2014.

Cubillos, J., Wright, S., Nash, G., de Salas, M., Griffiths, B., Tilbrook, B., Poisson, A., and Hallegraeff, G.: Calcification Morphotypes of the Coccolithophorid Emiliania Huxleyi in the Southern Ocean: Changes in 2001 to 2006 Compared to Historical Data, Marine Ecology Progress Series, 348, 47-54, https://doi.org/10.3354/meps07058, 2007.

Dávila, P. M., Figueroa, D., and Müller, E.: Freshwater Input into the Coastal Ocean and Its Relation with the Salinity Distribution off Austral Chile (35-55 ${ }^{\circ}$ ), Continental Shelf Research, 22, 521-534, https://doi.org/10.1016/S0278-4343(01)00072-3, 2002.

Dawson, H. R. S., Strutton, P. G., and Gaube, P.: The Unusual Surface Chlorophyll Signatures of Southern Ocean Eddies, Journal of Geophysical Research: Oceans, 123, 6053-6069, https://doi.org/10.1029/2017JC013628, 2018.

Deppeler, S. L. and Davidson, A. T.: Southern Ocean Phytoplankton in a Changing Climate, Frontiers in Marine Science, 4, https://doi.org/10.3389/fmars.2017.00040, 2017. 
https://doi.org/10.5194/bg-2021-105

Preprint. Discussion started: 23 April 2021

(C) Author(s) 2021. CC BY 4.0 License.

\section{(c) (i)}

Deuser, W. G., Muller-Karger, F. E., Evans, R. H., Brown, O. B., Esaias, W. E., and Feldman, G. C.: Surface-Ocean Color and Deep-Ocean Carbon Flux: How Close a Connection?, Deep Sea Research Part A. Oceanographic Research Papers, 37, 1331-1343, https://doi.org/10.1016/0198-0149(90)90046-X, 1990.

Díaz-Rosas, F., Alves-de-Souza, C., Alarcón, E., Menschel, E., González, H. E., Torres, R., and von Dassow, P.: Abundances and Morphotypes of the Coccolithophore Emiliania Huxleyi in Southern Patagonia Compared to Neighboring Oceans and Northern-Hemisphere Fjords, Biogeosciences Discussions, pp. 1-34, https://doi.org/10.5194/bg-2020-449, 2021.

Dittert, N., Baumann, K.-H., Bickert, T., Henrich, R., Huber, R., Kinkel, H., and Meggers, H.: Carbonate Dissolution in the Deep-Sea: Methods, Quantification and Paleoceanographic Application, in: Use of Proxies in Paleoceanography: Examples from the South Atlantic, edited by Fischer, G. and Wefer, G., pp. 255-284, Springer, Berlin, Heidelberg, https://doi.org/10.1007/978-3-642-58646-0_10, 1999.

Donohue, K. A., Tracey, K. L., Watts, D. R., Chidichimo, M. P., and Chereskin, T. K.: Mean Antarctic Circumpolar Current Transport Measured in Drake Passage, Geophysical Research Letters, 43, 11,760-11,767, https://doi.org/10.1002/2016GL070319, 2016.

Dray, S., Bauman, D., Blanchet, G., Borcard, D., Clappe, S., Guenard, G., Jombart, T., Larocque, G., Legendre, P., Madi, N., and Wagner, H. H.: Adespatial: Multivariate Multiscale Spatial Analysis, 2020.

Dylmer, C. V., Giraudeau, J., Hanquiez, V., and Husum, K.: The Coccolithophores Emiliania Huxleyi and Coccolithus Pelagicus: Extant Populations from the Norwegian-Iceland Seas and Fram Strait, Deep Sea Research Part I: Oceanographic Research Papers, 98, 1-9, https://doi.org/10.1016/j.dsr.2014.11.012, 2015.

Feng, Y., Roleda, M. Y., Armstrong, E., Law, C. S., Boyd, P. W., and Hurd, C. L.: Environmental Controls on the Elemental Composition of a Southern Hemisphere Strain of the Coccolithophore Emiliania Huxleyi, Biogeosciences, 15, 581-595, https://doi.org/10.5194/bg-15581-2018, 2018.

Findlay, C. S. and Giraudeau, J.: Extant Calcareous Nannoplankton in the Australian Sector of the Southern Ocean (Austral Summers 1994 and 1995), Marine Micropaleontology, 40, 417-439, https://doi.org/10.1016/S0377-8398(00)00046-3, 2000.

Findlay, C. S. and Giraudeau, J.: Movement of Oceanic Fronts South of Australia during the Last 10 Ka: Interpretation of Calcareous Nannoplankton in Surface Sediments from the Southern Ocean, Marine Micropaleontology, 46, 431-444, https://doi.org/10.1016/S03778398(02)00084-1, 2002.

Findlay, H. S., Calosi, P., and Crawfurd, K.: Determinants of the PIC : POC Response in the Coccolithophore Emiliania Huxleyi under Future Ocean Acidification Scenarios, Limnology and Oceanography, 56, 1168-1178, https://doi.org/10.4319/lo.2011.56.3.1168, 2011.

Flores, J.-A., Marino, M., Sierro, F. J., Hodell, D. A., and Charles, C. D.: Calcareous Plankton Dissolution Pattern and Coccolithophore Assemblages during the Last $600 \mathrm{Kyr}$ at ODP Site 1089 (Cape Basin, South Atlantic): Paleoceanographic Implications, Palaeogeography, Palaeoclimatology, Palaeoecology, 196, 409-426, https://doi.org/10.1016/S0031-0182(03)00467-X, 2003.

Flores, J. A., Filippelli, G. M., Sierro, F. J., and Latimer, J. C.: The "White Ocean” Hypothesis: A Late Pleistocene Southern Ocean Governed by Coccolithophores and Driven by Phosphorus, Frontiers in Microbiology, 3, https://doi.org/10.3389/fmicb.2012.00233, 2012.

Frölicher, T. L., Sarmiento, J. L., Paynter, D. J., Dunne, J. P., Krasting, J. P., and Winton, M.: Dominance of the Southern Ocean in Anthropogenic Carbon and Heat Uptake in CMIP5 Models, Journal of Climate, 28, 862-886, https://doi.org/10.1175/JCLI-D-14-00117.1, 2014.

760 Fuertes, M.-Á., Flores, J.-A., and Sierro, F. J.: The Use of Circularly Polarized Light for Biometry, Identification and Estimation of Mass of Coccoliths, Marine Micropaleontology, 113, 44-55, https://doi.org/10.1016/j.marmicro.2014.08.007, 2014.

Gard, G.: Late Quaternary Coccoliths at the North Pole: Evidence of Ice-Free Conditions and Rapid Sedimentation in the Central Arctic Ocean, Geology, 21, 227-230, https://doi.org/10.1130/0091-7613(1993)021<0227:LQCATN>2.3.CO;2, 1993. 
https://doi.org/10.5194/bg-2021-105

Preprint. Discussion started: 23 April 2021

(c) Author(s) 2021. CC BY 4.0 License.

(c) (i)

Gardner, J., Manno, C., Bakker, D. C. E., Peck, V. L., and Tarling, G. A.: Southern Ocean Pteropods at Risk from Ocean Warming and Acidification, Marine Biology, 165, 8, https://doi.org/10.1007/s00227-017-3261-3, 2018.

Giglio, D. and Johnson, G. C.: Subantarctic and Polar Fronts of the Antarctic Circumpolar Current and Southern Ocean Heat and Freshwater Content Variability: A View from Argo, Journal of Physical Oceanography, 46, 749-768, https://doi.org/10.1175/JPO-D-15-0131.1, 2016.

Gravalosa, J. M., Flores, J.-A., Sierro, F. J., and Gersonde, R.: Sea Surface Distribution of Coccolithophores in the Eastern Pacific Sector of the Southern Ocean (Bellingshausen and Amundsen Seas) during the Late Austral Summer of 2001, Marine Micropaleontology, 69, 16-25, https://doi.org/10.1016/j.marmicro.2007.11.006, 2008.

Hagino, K., Bendif, E. M., Young, J. R., Kogame, K., Probert, I., Takano, Y., Horiguchi, T., de Vargas, C., and Okada, H.: New Evidence for Morphological and Genetic Variation in the Cosmopolitan Coccolithophore Emiliania Huxleyi (Prymnesiophyceae) from the Cox 1b-Atp4 Genes, Journal of Phycology, 47, 1164-1176, https://doi.org/10.1111/j.1529-8817.2011.01053.x, 2011.

Hernández-Almeida, I., Ausín, B., Saavedra-Pellitero, M., Baumann, K.-H., and Stoll, H.: Quantitative Reconstruction of Primary Productivity in Low Latitudes during the Last Glacial Maximum and the Mid-to-Late Holocene from a Global Florisphaera Profunda Calibration Dataset, Quaternary Science Reviews, 205, 166-181, https://doi.org/10.1016/j.quascirev.2018.12.016, 2019.

Ho, S. L., Mollenhauer, G., Lamy, F., Martínez-García, A., Mohtadi, M., Gersonde, R., Hebbeln, D., Nunez-Ricardo, S., Rosell-Melé, A., and Tiedemann, R.: Depth-Age Pointers and Linear Sedimentation Rates of Sediment Core PS75/034-2, https://doi.org/10.1594/PANGAEA.792636, 2012.

Hofmann, E. E.: The Large-Scale Horizontal Structure of the Antarctic Circumpolar Current from FGGE Drifters, Journal of Geophysical Research: Oceans, 90, 7087-7097, https://doi.org/10.1029/JC090iC04p07087, 1985.

Holligan, P. M., Charalampopoulou, A., and Hutson, R.: Seasonal Distributions of the Coccolithophore, Emiliania Huxleyi, and of Particulate Inorganic Carbon in Surface Waters of the Scotia Sea, Journal of Marine Systems, 82, 195-205, https://doi.org/10.1016/j.jmarsys.2010.05.007, 2010.

Holte, J., Talley, L. D., Gilson, J., and Roemmich, D.: An Argo Mixed Layer Climatology and Database: ARGO MLD CLIMATOLOGY, Geophysical Research Letters, 44, 5618-5626, https://doi.org/10.1002/2017GL073426, 2017.

Honjo, S.: Coccoliths: Production, Transportation and Sedimentation, Marine Micropaleontology, 1, 65-79, https://doi.org/10.1016/03778398(76)90005-0, 1976.

Jeanmougin, M., Lee, N., and various: Inkscape: Open Source Scalable Vector Graphics Editor, 2021.

Kaiser, J., Lamy, F., and Hebbeln, D.: A 70-Kyr Sea Surface Temperature Record off Southern Chile (Ocean Drilling Program Site 1233), Paleoceanography, 20, https://doi.org/10.1029/2005PA001146, 2005.

Karstensen, J. and Ulloa, O.: Peru-Chile Current System, in: Encyclopedia of Ocean Sciences (Second Edition), edited by Steele, J. H., pp. 385-392, Academic Press, Oxford, https://doi.org/10.1016/B978-012374473-9.00599-3, 2009.

Key, R., Olsen, A., Van Heuven, S., Lauvset, S., Velo, A., Lin, X., Schirnick, C., Kozyr, A., Tanhua, T., Hoppema, M., Jutterstrom, S., Steinfeldt, R., Jeansson, E., Ishi, M., Perez, F., and Suzuki, T.: Global Ocean Data Analysis Project, Version 2 (GLODAPv2), ORNL/CDIAC162, ND-P093, https://doi.org/10.3334/CDIAC/OTG.NDP093_GLODAPV2, 2015.

Kim, Y. S. and Orsi, A. H.: On the Variability of Antarctic Circumpolar Current Fronts Inferred from 1992-2011 Altimetry, Journal of Physical Oceanography, 44, 3054-3071, https://doi.org/10.1175/JPO-D-13-0217.1, 2014.

Kohfeld, K. E. and Ridgwell, A.: Glacial-Interglacial Variability in Atmospheric CO2, in: Surface Ocean-Lower Atmosphere Processes, pp. 251-286, American Geophysical Union (AGU), https://doi.org/10.1029/2008GM000845, 2009. 
https://doi.org/10.5194/bg-2021-105

Preprint. Discussion started: 23 April 2021

(c) Author(s) 2021. CC BY 4.0 License.

(c) (i)

Krumhardt, K. M., Lovenduski, N. S., Long, M. C., Levy, M., Lindsay, K., Moore, J. K., and Nissen, C.: Coccolithophore Growth and Calcification in an Acidified Ocean: Insights From Community Earth System Model Simulations, Journal of Advances in Modeling Earth Systems, 11, 1418-1437, https://doi.org/10.1029/2018MS001483, 2019.

Krumhardt, K. M., Long, M. C., Lindsay, K., and Levy, M. N.: Southern Ocean Calcification Controls the Global Distribution of Alkalinity, Global Biogeochemical Cycles, 34, e2020GB006 727, https://doi.org/10.1029/2020GB006727, 2020.

Lamy, F.: The Expedition PS97 of the Research Vessel POLARSTERN to the Drake Passage in 2016, Tech. rep., Alfred-Wegener-Institut, Helmholtz-Zentrum für Polar- und Meeresforschung, https://doi.org/10.2312/BZPM_0701_2016, 2016.

Lamy, F., Arz, H. W., Kilian, R., Lange, C. B., Lembke-Jene, L., Wengler, M., Kaiser, J., Baeza-Urrea, O., Hall, I. R., Harada, N., and Tiedemann, R.: Glacial Reduction and Millennial-Scale Variations in Drake Passage Throughflow, Proceedings of the National Academy of Sciences, 112, 13 496-13 501, https://doi.org/10.1073/pnas.1509203112, 2015.

Lauvset, S. K., Key, R. M., Olsen, A., van Heuven, S., Velo, A., Lin, X., Schirnick, C., Kozyr, A., Tanhua, T., Hoppema, M., Jutterström, S., Steinfeldt, R., Jeansson, E., Ishii, M., Perez, F. F., Suzuki, T., and Watelet, S.: A New Global Interior Ocean Mapped Climatology: The ${ }^{\circ}$ $\times 1^{\circ}$ GLODAP Version 2, Earth System Science Data, 8, 325-340, https://doi.org/10.5194/essd-8-325-2016, 2016.

Legendre, P. and Gallagher, E. D.: Ecologically Meaningful Transformations for Ordination of Species Data, Oecologia, 129, 271-280, 2001.

Lin, J., Lee, Z., Ondrusek, M., and Du, K.: Remote Sensing of Normalized Diffuse Attenuation Coefficient of Downwelling Irradiance: REMOTE SENSING OF NKD, Journal of Geophysical Research: Oceans, 121, 6717-6730, https://doi.org/10.1002/2016JC011895, 2016.

Malinverno, E., Triantaphyllou, M. V., and Dimiza, M. D.: Coccolithophore Assemblage Distribution along a Temperate to Polar Gradient in the West Pacific Sector of the Southern Ocean (January 2005), Micropaleontology, 61, 489-506, 2015.

Malinverno, E., Maffioli, P., and Gariboldi, K.: Latitudinal Distribution of Extant Fossilizable Phytoplankton in the Southern Ocean: Planktonic Provinces, Hydrographic Fronts and Palaeoecological Perspectives, Marine Micropaleontology, 123, 41-58, https://doi.org/10.1016/j.marmicro.2016.01.001, 2016.

Malone, T.: Chapter 6 Primary Production, Cycling of Nutrients, Surface Layer and Plankton, in: First Global Marine Assessment, p. 67, Oceans and Law of the Sea, United Nations, 2016.

Menschel, E., González, H. E., and Giesecke, R.: Coastal-Oceanic Distribution Gradient of Coccolithophores and Their Role in the Carbonate Flux of the Upwelling System off Concepción, Chile (36 ${ }^{\circ}$ ), Journal of Plankton Research, 38, 798-817, https://doi.org/10.1093/plankt/fbw037, 2016.

Meyer, J. and Riebesell, U.: Reviews and Syntheses: Responses of Coccolithophores to Ocean Acidification: A Meta-Analysis, Biogeosciences, 12, 1671-1682, https://doi.org/10.5194/bg-12-1671-2015, 2015.

Mohan, R., Mergulhao, L. P., Guptha, M., Rajakumar, A., Thamban, M., AnilKumar, N., Sudhakar, M., and Ravindra, R.: Ecology of Coccolithophores in the Indian Sector of the Southern Ocean, Marine Micropaleontology, 67, 30-45, https://doi.org/10.1016/j.marmicro.2007.08.005, 2008.

Morrison, A. K., Frölicher, T. L., and Sarmiento, J. L.: Upwelling in the Southern Ocean, Physics Today, 68, 27-32, https://doi.org/10.1063/PT.3.2654, 2014

Müller, M. N., Trull, T. W., and Hallegraeff, G. M.: Differing Responses of Three Southern Ocean Emiliania Huxleyi Ecotypes to Changing Seawater Carbonate Chemistry, Marine Ecology Progress Series, 531, 81-90, https://doi.org/10.3354/meps11309, 2015.

Murtugudde, R., Beauchamp, J., McClain, C. R., Lewis, M., and Busalacchi, A. J.: Effects of Penetrative Radiation on the Upper Tropical Ocean Circulation, Journal of Climate, 15, 470-486, https://doi.org/10.1175/1520-0442(2002)015<0470:EOPROT>2.0.CO;2, 2002. 
https://doi.org/10.5194/bg-2021-105

Preprint. Discussion started: 23 April 2021

(c) Author(s) 2021. CC BY 4.0 License.

(c) (i)

NASA/JPL: GHRSST Level 2P Global Sea Surface Skin Temperature from the Moderate Resolution Imaging Spectroradiometer (MODIS) on the NASA Aqua Satellite (GDS2), https://doi.org/10.5067/GHMDA-2PJ19, 2020.

840 Neukermans, G., Oziel, L., and Babin, M.: Increased Intrusion of Warming Atlantic Water Leads to Rapid Expansion of Temperate Phytoplankton in the Arctic, Global Change Biology, 24, 2545-2553, https://doi.org/10.1111/gcb.14075, 2018.

Nghiem, S. V., Rigor, I. G., Clemente-Colón, P., Neumann, G., and Li, P. P.: Geophysical Constraints on the Antarctic Sea Ice Cover, Remote Sensing of Environment, 181, 281-292, https://doi.org/10.1016/j.rse.2016.04.005, 2016.

Nissen, C., Vogt, M., Münnich, M., Gruber, N., and Haumann, F. A.: Factors Controlling Coccolithophore Biogeography in the Southern Ocean, Biogeosciences, 15, 6997-7024, https://doi.org/10.5194/bg-15-6997-2018, 2018.

Nooteboom, P. D., Bijl, P. K., van Sebille, E., von der Heydt, A. S., and Dijkstra, H. A.: Transport Bias by Ocean Currents in Sedimentary Microplankton Assemblages: Implications for Paleoceanographic Reconstructions, Paleoceanography and Paleoclimatology, 34, 11781194, https://doi.org/10.1029/2019PA003606, 2019.

Nooteboom, P. D., Delandmeter, P., van Sebille, E., Bijl, P. K., Dijkstra, H. A., and von der Heydt, A. S.: Resolution Dependency of Sinking Lagrangian Particles in Ocean General Circulation Models, PLOS ONE, 15, e0238 650, https://doi.org/10.1371/journal.pone.0238650, 2020.

Oksanen, J., Blanchet, F. G., Friendly, M., Kindt, R., Legendre, P., McGlinn, D., Minchin, P. R., O’Hara, R. B., Simpson, G. L., Solymos, P., Stevens, M. H. H., Szoecs, E., and Wagner, H.: Vegan: Community Ecology Package, 2019.

O’Regan, M., Backman, J., Fornaciari, E., Jakobsson, M., and West, G.: Calcareous Nannofossils Anchor Chronologies for Arctic Ocean Sediments Back to $500 \mathrm{Ka}$, Geology, 48, 1115-1119, https://doi.org/10.1130/G47479.1, 2020.

Orsi, A. H., Whitworth, T., and Nowlin, W. D.: On the Meridional Extent and Fronts of the Antarctic Circumpolar Current, Deep Sea Research Part I: Oceanographic Research Papers, 42, 641-673, https://doi.org/10.1016/0967-0637(95)00021-W, 1995.

Oziel, L., Baudena, A., Ardyna, M., Massicotte, P., Randelhoff, A., Sallée, J.-B., Ingvaldsen, R. B., Devred, E., and Babin, M.: Faster Atlantic Currents Drive Poleward Expansion of Temperate Phytoplankton in the Arctic Ocean, Nature Communications, 11, 1705, https://doi.org/10.1038/s41467-020-15485-5, 2020.

Palter, J. B., Sarmiento, J. L., Gnanadesikan, A., Simeon, J., and Slater, R. D.: Fueling Export Production: Nutrient Return Pathways from the Deep Ocean and Their Dependence on the Meridional Overturning Circulation, Biogeosciences, 7, 3549-3568, https://doi.org/10.5194/bg7-3549-2010, 2010.

Palter, J. B., Marinov, I., Sarmiento, J. L., and Gruber, N.: Large-Scale, Persistent Nutrient Fronts of the World Ocean: Impacts on Biogeochemistry, Springer Berlin Heidelberg, Berlin, Heidelberg, https://doi.org/10.1007/698_2013_241, 2013.

Park, Y.-H. and Durand, I.: Altimetry-Drived Antarctic Circumpolar Current Fronts, https://doi.org/10.17882/59800, 2019.

Park, Y.-H., Park, T., Kim, T.-W., Lee, S.-H., Hong, C.-S., Lee, J.-H., Rio, M.-H., Pujol, M.-I., Ballarotta, M., Durand, I., and Provost, C.: Observations of the Antarctic Circumpolar Current Over the Udintsev Fracture Zone, the Narrowest Choke Point in the Southern Ocean, Journal of Geophysical Research: Oceans, 124, 4511-4528, https://doi.org/10.1029/2019JC015024, 2019.

Patil, S. M., Rahul, M., Suhas, S., and Sahina, G.: Phytoplankton Abundance and Community Structure in the Antarctic Polar Frontal Region during Austral Summer of 2009, Chinese Journal of Oceanology and Limnology, 31, 21-30, https://doi.org/10.1007/s00343-013-1309-x, 2013.

Patil, S. M., Mohan, R., Shetye, S., Gazi, S., and Jafar, S.: Morphological Variability of Emiliania Huxleyi in the Indian Sector of the Southern Ocean during the Austral Summer of 2010, Marine Micropaleontology, 107, 44-58, https://doi.org/10.1016/j.marmicro.2014.01.005, 2014. 
https://doi.org/10.5194/bg-2021-105

Preprint. Discussion started: 23 April 2021

(c) Author(s) 2021. CC BY 4.0 License.

\section{(c) (i)}

Pierrot, D., Lewis, E., and Wallace, D.: MS Excel Program Developed for CO2 System Calculations, https://doi.org/10.3334/CDIAC/OTG.CO2SYS_XLS_CDIAC105A, 2012.

Poulton, A. J., Young, J. R., Bates, N. R., and Balch, W. M.: Biometry of Detached Emiliania Huxleyi Coccoliths along the Patagonian Shelf, Marine Ecology Progress Series, 443, 1-17, https://doi.org/10.3354/meps09445, 2011.

R Core Team: R: A Language and Environment for Statistical Computing, 2020.

Raymond, B.: Pelagic Regionalisation, in: Biogeographic Atlas of the Southern Ocean, edited by De Broyer, C., Koubbi, P., Griffiths, H., Raymond, B., d'Udekem d'Acoz, C., Van de Putte, A., Danis, B., David, B., Grant, S., Gutt, J., Held, C., Hosie, G., Huettmann, F., Post, A., and Ropert-Coudert, Y., pp. 418-421, Scientific Committee on Antarctic Research, Cambridge UK, 2014.

Rembauville, M., Meilland, J., Ziveri, P., Schiebel, R., Blain, S., and Salter, I.: Planktic Foraminifer and Coccolith Contribution to Carbonate Export Fluxes over the Central Kerguelen Plateau, Deep Sea Research Part I: Oceanographic Research Papers, 111, 91-101, https://doi.org/10.1016/j.dsr.2016.02.017, 2016.

Renault, A., Provost, C., Sennéchael, N., Barré, N., and Kartavtseff, A.: Two Full-Depth Velocity Sections in the Drake Passage in 2006-Transport Estimates, Deep Sea Research Part II: Topical Studies in Oceanography, 58, 2572-2591, https://doi.org/10.1016/j.dsr2.2011.01.004, 2011.

Riaux-Gobin, C., Fontugne, M., Jensen, K. G., Bentaleb, I., Cauwet, G., Chrétiennot-Dinet, M. J., and Poisson, A.: Surficial Deep-Sea Sediments across the Polar Frontal System (Southern Ocean, Indian Sector): Particulate Carbon Content and Microphyte Signatures, Marine Geology, 230, 147-159, https://doi.org/10.1016/j.margeo.2006.04.005, 2006.

Rigual Hernández, A. S., Flores, J. A., Sierro, F. J., Fuertes, M. A., Cros, L., and Trull, T. W.: Coccolithophore Populations and Their Contribution to Carbonate Export during an Annual Cycle in the Australian Sector of the Antarctic Zone, Biogeosciences, 15, 1843-1862, https://doi.org/10.5194/bg-15-1843-2018, 2018.

Rigual-Hernández, A. S., Trull, T. W., Flores, J. A., Nodder, S. D., Eriksen, R., Davies, D. M., Hallegraeff, G. M., Sierro, F. J., Patil, S. M., Cortina, A., Ballegeer, A. M., Northcote, L. C., Abrantes, F., and Rufino, M. M.: Full Annual Monitoring of Subantarctic Emiliania Huxleyi Populations Reveals Highly Calcified Morphotypes in High-CO2 Winter Conditions, Scientific Reports, 10, 2594, https://doi.org/10.1038/s41598-020-59375-8, 2020.

Rigual Hernández, A. S., Trull, T. W., Nodder, S. D., Flores, J. A., Bostock, H., Abrantes, F., Eriksen, R. S., Sierro, F. J., Davies, D. M., Ballegeer, A.-M., Fuertes, M. A., and Northcote, L. C.: Coccolithophore Biodiversity Controls Carbonate Export in the Southern Ocean, Biogeosciences, 17, 245-263, https://doi.org/10.5194/bg-17-245-2020, 2020.

Rintoul, S. R.: The Global Influence of Localized Dynamics in the Southern Ocean, Nature, 558, 209-218, https://doi.org/10.1038/s41586018-0182-3, 2018.

Rivas, L., Panera, J. P. P., Alperin, M., and Cusminsky, G.: Calcareous Nannoplankton Thanatocoenosis Distribution in the Southwestern Atlantic Ocean: New Evidence in the Western Malvinas Current Gyre, 17th INA Conference, Santos, Brazil, $90,2019$.

Rost, B. and Riebesell, U.: Coccolithophores and the Biological Pump: Responses to Environmental Changes, in: Coccolithophores. From Molecular Processes to Global Impact, edited by Thierstein, H. R. and Young, J. R., pp. 99-125, Springer, Berlin, Heidelberg, https://doi.org/10.1007/978-3-662-06278-4_5, 2004.

910 Saavedra-Pellitero, M. and Baumann, K.-H.: Comparison of Living and Surface Sediment Coccolithophore Assemblages in the Pacific Sector of the Southern Ocean, 61, 14, 2015.

Saavedra-Pellitero, M., Flores, J.-A., Baumann, K.-H., and Sierro, F.-J.: Coccolith Distribution Patterns in Surface Sediments of Equatorial and Southeastern Pacific Ocean, Geobios, 43, 131-149, https://doi.org/10.1016/j.geobios.2009.09.004, 2010. 
https://doi.org/10.5194/bg-2021-105

Preprint. Discussion started: 23 April 2021

(C) Author(s) 2021. CC BY 4.0 License.

\section{(c) (i)}

Saavedra-Pellitero, M., Flores, J. A., Lamy, F., Sierro, F. J., and Cortina, A.: Coccolithophore Estimates of Paleotemperature and Paleoproductivity Changes in the Southeast Pacific over the Past 27 Kyr, Paleoceanography, 26, PA1201, https://doi.org/10.1029/2009PA001824, 2011.

Saavedra-Pellitero, M., Baumann, K. H., Hernández-Almeida, I., Flores, J. A., and Sierro, F. J.: Modern Sea Surface Productivity and Temperature Estimations off Chile as Detected by Coccolith Accumulation Rates, Palaeogeography, Palaeoclimatology, Palaeoecology, 392, 534-545, https://doi.org/10.1016/j.palaeo.2013.10.010, 2013.

Saavedra-Pellitero, M., Baumann, K.-H., Flores, J.-A., and Gersonde, R.: Biogeographic Distribution of Living Coccolithophores in the Pacific Sector of the Southern Ocean, Marine Micropaleontology, 109, 1-20, https://doi.org/10.1016/j.marmicro.2014.03.003, 2014.

Saavedra-Pellitero, M., Baumann, K.-H., Lamy, F., and Köhler, P.: Coccolithophore Variability across Marine Isotope Stage 11 in the Pacific Sector of the Southern Ocean and Its Potential Impact on the Carbon Cycle, Paleoceanography, 32, 864-880, https://doi.org/10.1002/2017PA003156, 2017.

Saavedra-Pellitero, M., Baumann, K.-H., Ullermann, J., and Lamy, F.: Marine Isotope Stage 11 in the Pacific Sector of the Southern Ocean; a Coccolithophore Perspective, Quaternary Science Reviews, 158, 1-14, https://doi.org/10.1016/j.quascirev.2016.12.020, 2017.

Saavedra-Pellitero, M., Baumann, K.-H., Fuertes, M. Á., Schulz, H., Marcon, Y., Vollmar, N. M., Flores, J.-A., and Lamy, F.: Calcification and Latitudinal Distribution of Extant Coccolithophores across the Drake Passage during Late Austral Summer 2016, Biogeosciences, 16, 3679-3702, https://doi.org/10.5194/bg-16-3679-2019, 2019.

Saldías, G. S., Sobarzo, M., and Quiñones, R.: Freshwater Structure and Its Seasonal Variability off Western Patagonia, Progress in Oceanography, 174, 143-153, https://doi.org/10.1016/j.pocean.2018.10.014, 2019.

Sarmiento, J. L., Slater, R., Barber, R., Bopp, L., Doney, S. C., Hirst, A. C., Kleypas, J., Matear, R., Mikolajewicz, U., Monfray, P., Soldatov, V., Spall, S. A., and Stouffer, R.: Response of Ocean Ecosystems to Climate Warming, Global Biogeochemical Cycles, 18, n/a-n/a, https://doi.org/10.1029/2003GB002134, 2004.

Saruwatari, K., Satoh, M., Harada, N., Suzuki, I., and Shiraiwa, Y.: Change in Coccolith Size and Morphology Due to Response to Temperature and Salinity in Coccolithophore Emiliania Huxleyi (Haptophyta) Isolated from the Bering and Chukchi Seas, Biogeosciences, 13 , 2743-2755, https://doi.org/10.5194/bg-13-2743-2016, 2016.

Schindelin, J., Arganda-Carreras, I., Frise, E., Kaynig, V., Longair, M., Pietzsch, T., Preibisch, S., Rueden, C., Saalfeld, S., Schmid, B., Tinevez, J.-Y., White, D. J., Hartenstein, V., Eliceiri, K., Tomancak, P., and Cardona, A.: Fiji: An Open-Source Platform for BiologicalImage Analysis, Nature Methods, 9, 676-682, https://doi.org/10.1038/nmeth.2019, 2012.

Smith, H. E. K., Poulton, A. J., Garley, R., Hopkins, J., Lubelczyk, L. C., Drapeau, D. T., Rauschenberg, S., Twining, B. S., Bates, N. R., and Balch, W. M.: The Influence of Environmental Variability on the Biogeography of Coccolithophores and Diatoms in the Great Calcite Belt, Biogeosciences, 14, 4905-4925, https://doi.org/10.5194/bg-14-4905-2017, 2017.

Smyth, T. J., Tyrrell, T., and Tarrant, B.: Time Series of Coccolithophore Activity in the Barents Sea, from Twenty Years of Satellite Imagery, Geophysical Research Letters, 31, https://doi.org/10.1029/2004GL019735, 2004.

Sokolov, S. and Rintoul, S. R.: Circumpolar Structure and Distribution of the Antarctic Circumpolar Current Fronts: 1. Mean Circumpolar Paths, Journal of Geophysical Research: Oceans, 114, https://doi.org/10.1029/2008JC005108, 2009.

Steinmetz, J.: Sedimentation of Coccolithophores, in: Coccolithophores, edited by Winter, A. and Siesser, W., pp. 17p-197, Cambridge University Press, Cambridge, 1994.

950 Strub, P. T., Mesias, J. M., Montecino, V., Rutllant, J., and Salinas, S.: Coastal Ocean Circulation off Western South America. Coastal Segment, in: The Sea, edited by A.R. Robinson and K.H. Bring, vol. 11, pp. 273-313, John Wiley \& Sons, Inc., New York, 1998. 
https://doi.org/10.5194/bg-2021-105

Preprint. Discussion started: 23 April 2021

(c) Author(s) 2021. CC BY 4.0 License.

\section{(c) (i)}

Sulpis, O., Boudreau, B. P., Mucci, A., Jenkins, C., Trossman, D. S., Arbic, B. K., and Key, R. M.: Current CaCO3 Dissolution at the Seafloor Caused by Anthropogenic CO2, Proceedings of the National Academy of Sciences, 115, 11700-11705, https://doi.org/10.1073/pnas.1804250115, 2018.

Suzuki, R., Terada, Y., and Shimodaira, H.: Pvclust: Hierarchical Clustering with P-Values via Multiscale Bootstrap Resampling, 2019.

Talley, L. D., Pickard, G. L., Emery, W. J., and Swift, J. H.: Southern Ocean, in: Descriptive Physical Oceanography, pp. 437-471, Elsevier, https://doi.org/10.1016/B978-0-7506-4552-2.10013-7, 2011.

Telford, R.: Ggpalaeo: Ggplot2 Plots For Analogue and Rioja Packages, 2019.

Toyos, M. H., Lamy, F., Lange, C. B., Lembke-Jene, L., Saavedra-Pellitero, M., Esper, O., and Arz, H. W.: Antarctic Circumpolar Current Dynamics at the Pacific Entrance to the Drake Passage Over the Past 1.3 Million Years, Paleoceanography and Paleoclimatology, 35, e2019PA003 773, https://doi.org/10.1029/2019PA003773, 2020.

van Sebille, E., Scussolini, P., Durgadoo, J. V., Peeters, F. J. C., Biastoch, A., Weijer, W., Turney, C., Paris, C. B., and Zahn, R.: Ocean Currents Generate Large Footprints in Marine Palaeoclimate Proxies, Nature Communications, 6, 6521, https://doi.org/10.1038/ncomms7521, 2015.

Volk, T. and Hoffert, M. I.: Ocean Carbon Pumps: Analysis of Relative Strengths and Efficiencies in Ocean-Driven Atmospheric CO2 Changes, in: The Carbon Cycle and Atmospheric CO2: Natural Variations Archean to Present, pp. 99-110, American Geophysical Union (AGU), https://doi.org/10.1029/GM032p0099, 1985.

von Dassow, P., Díaz-Rosas, F., Bendif, E. M., Gaitán-Espitia, J.-D., Mella-Flores, D., Rokitta, S., John, U., and Torres, R.: Over-Calcified Forms of the Coccolithophore Emiliania Huxleyi in High-CO2 Waters Are Not Preadapted to Ocean Acidification, Biogeosciences, 15, 1515-1534, https://doi.org/10.5194/bg-15-1515-2018, 2018.

Vorrath, M.-E., Müller, J., Esper, O., Mollenhauer, G., Haas, C., Schefuß, E., and Fahl, K.: Radiocarbon Ages from Surface Sediments, Southern Drake Passage and the Bransfield Strait, Antarctic Peninsula, https://doi.org/10.1594/PANGAEA.897163, 2019.

Wickham, H.: Ggplot2: Elegant Graphics for Data Analysis, Use R!, Springer International Publishing : Imprint: Springer, Cham, 2nd ed. 2016 edn., https://doi.org/10.1007/978-3-319-24277-4, 2016.

Winter, A., Elbrächter, M., and Krause, G.: Subtropical Coccolithophores in the Weddell Sea, Deep Sea Research Part I: Oceanographic Research Papers, 46, 439-449, https://doi.org/10.1016/S0967-0637(98)00076-4, 1999.

Winter, A., Henderiks, J., Beaufort, L., Rickaby, R. E. M., and Brown, C. W.: Poleward Expansion of the Coccolithophore Emiliania Huxleyi, Journal of Plankton Research, 36, 316-325, https://doi.org/10.1093/plankt/fbt110, 2013.

Winter, A., Henderiks, J., Beaufort, L., Rickaby, R. E. M., and Brown, C. W.: Poleward Expansion of the Coccolithophore Emiliania Huxleyi, Journal of Plankton Research, 36, 316-325, https://doi.org/10.1093/plankt/fbt110, 2014.

Wu, S., Kuhn, G., Diekmann, B., Lembke-Jene, L., Tiedemann, R., Zheng, X., Ehrhardt, S., Arz, H. W., and Lamy, F.: Surface Sediment Characteristics Related to Provenance and Ocean Circulation in the Drake Passage Sector of the Southern Ocean, Deep Sea Research Part I: Oceanographic Research Papers, 154, 103 135, https://doi.org/10.1016/j.dsr.2019.103135, 2019.

Young, J.: Coccobiom2 Macros, http://ina.tmsoc.org/nannos/coccobiom/Usernotes.html, 2015.

Young, J., Geisen, M., Cros, L., Kleijne, A., Sprengel, C., Probert, I., and Ostergaard, J.: A Guide to Extant Coccolithophore Taxonomy, Journal of Nannoplankton Research, 2003.

Young, J., Geisen, M., and Probert, I.: A Review of Selected Aspects of Coccolithophore Biology with Implications for Paleobiodiversity Estimation, Micropaleontology, 51, 267-288, https://doi.org/10.2113/gsmicropal.51.4.267, 2005.

Young, J., Bown, P., and Lees, J.: Nannotax3 Website. International Nannoplankton Association, http://www.mikrotax.org/Nannotax3/, 2020. 
https://doi.org/10.5194/bg-2021-105

Preprint. Discussion started: 23 April 2021

(c) Author(s) 2021. CC BY 4.0 License.

(c) (i)

990 Young, J. R. and Ziveri, P.: Calculation of Coccolith Volume and It Use in Calibration of Carbonate Flux Estimates, Deep Sea Research Part II: Topical Studies in Oceanography, 47, 1679-1700, https://doi.org/10.1016/S0967-0645(00)00003-5, 2000.

Young, J. R., Bown, P., and Lees, J.: Emiliania Huxleyi B Group, http://archive.is/lBgdd.

Zeebe, R. E.: History of Seawater Carbonate Chemistry, Atmospheric $\mathrm{CO}_{2}$, and Ocean Acidification, Annual Review of Earth and Planetary Sciences, 40, 141-165, https://doi.org/10.1146/annurev-earth-042711-105521, 2012. 